\title{
Properties of flexural and impact of matrix composites polyester reinforced with
}

\section{short lignocellulosic fibers}

Propriedades de flexão e impacto de compósitos de matriz poliéster reforçados com fỉbras

\section{lignocelulósicas curtas}

\section{Propiedades de flexión e impacto de compuestos de matriz de poliéster reforzados con fibras}

\section{lignocelulósicas cortas}

Heictor Alves de Oliveira Costa

ORCID: https://orcid.org/0000-0003-3611-3675 Federal University of Pará, Brazil

E-mail: heictor8@gmail.com

Fernando José Aguirre Ramos da Silva ORCID: https://orcid.org/0000-0002-4754-1416 Federal Institute of Education, Science and Technology of Pará, Brazil

E-mail: aguirrefernando.ifpa@gmail.com

Alessandro José Gomes dos Santos ORCID: https://orcid.org/0000-0002-9892-6682 Federal University of Pará, Brazil E-mail: ajgs@ufpa.br

Marcelo Henrique Prado da Silva ORCID: https://orcid.org/0000-0002-1182-5345 Materials Science Program, Military Institute of Engineering, Brazil E-mail: marceloprado@ime.eb.br

Roberto Tetsuo Fujiyama

ORCID: https://orcid.org/0000-0002-2738-6666 Federal University of Pará, Brazil E-mail: fujiyama@ufpa.br

\begin{abstract}
Composite materials stand out for enabling the development of new materials that are environmentally friendly, whose manufacturing processes and waste are increasingly less harmful, associated with good mechanical properties. In this context, this work sought to investigate the mechanical behavior in flexural and impact of polyester matrix composites with the inclusion of short fibers of sisal, piassava, raffia, mallow and jute arranged randomly. The mechanical properties of flexural were evaluated according to ASTM D 790 and the impact toughness Charpy with the ASTM D 6110 standard. The results showed that when subjected to flexural stresses, the composites presented resistance of $112.12 \mathrm{MPa}$ for the neat matrix and $35.21 ; 34.45 ; 27.29 ; 25.89$ and $20.56 \mathrm{MPa}$ with the inclusion of sisal, piassava, raffia, mallow and jute fibers, respectively. As for the impact test, they showed values of $31.50 \mathrm{~kJ} / \mathrm{m}^{2}$ for the neat matrix and $57.06 ; 52.52$; $48.03 ; 38.02 ; 37.65 \mathrm{~kJ} / \mathrm{m}^{2}$ with the inclusion of sisal, piassava, raffia, mallow and jute fibers, respectively. Then, the
\end{abstract}


fracture surface of the composites was analyzed with a microscope in order to correlate the fracture aspects with the mechanical properties.

Keywords: Vegetable fibers; Composite materials; Tensile test; Impact test.

\section{Resumo}

Os materiais compósitos destacam-se por possibilitarem o desenvolvimento de novos materiais que sejam ambientalmente corretos, cujos processos de fabricação e rejeitos sejam cada vez menos nocivos, associado à boas propriedades mecânicas. Neste contexto, este trabalho buscou investigar o comportamento mecânico em flexão e impacto de compósitos de matriz poliéster com a inclusão de fibras curtas de sisal, piaçava, palha da costa, malva e juta dispostas aleatoriamente. As propriedades mecânicas de flexão foram avaliadas de acordo com a norma ASTM D 790 e as de tenacidade ao impacto Charpy com a norma ASTM D 6110. Os resultados demonstraram que quando submetidos aos esforços de flexão, os compósitos apresentaram resistência de 112,12 MPa para a matriz plena e 35,21; 34,45; 27,29; 25,89 e 20,56 MPa com a inclusão de fibras de sisal, piaçava, palha da costa, malva e juta, respectivamente. Já para o ensaio de impacto apresentaram valores de $31,50 \mathrm{~kJ} / \mathrm{m}^{2}$ para a matriz plena e 57,$06 ; 52,52 ; 48,03 ; 38,02 ; 37,65 \mathrm{~kJ} / \mathrm{m}^{2}$ com a inclusão de fibras de sisal, piaçava, palha da costa, malva e juta, respectivamente. Em seguida foi analisada a superfície de fratura dos compósitos com microscópio afim de correlacionar os aspectos de fratura com as propriedades mecânicas.

Palavras-chave: Fibras vegetais; Materiais compósitos; Ensaio de tração; Ensaio de impacto.

\section{Resumen}

Los materiales compuestos destacan por permitir el desarrollo de nuevos materiales respetuosos con el medio ambiente, cuyos procesos de fabricación y residuos son cada vez menos nocivos, asociados a buenas propiedades mecánicas. En este contexto, este trabajo buscó investigar el comportamiento mecánico en flexión e impacto de compuestos de matriz de poliéster con la inclusión de fibras cortas de sisal, piassava, paja de la costa, mallow y yute dispuestas al azar. Las propiedades mecánicas a la flexión se evaluaron según la norma ASTM D 790 y la tenacidad al impacto Charpy según la norma ASTM D 6110. Los resultados mostraron que al ser sometidos a esfuerzos de flexión, los compuestos presentaron una resistencia de 112.12 MPa para la matriz completa es de $35.21 ; 34,45 ; 27,29 ; 25,89$ y 20,56 MPa con la inclusión de fibras de sisal, piassava, paja costera, mallow y yute, respectivamente. En cuanto a la prueba de impacto, presentaron valores de $31,50 \mathrm{~kJ} / \mathrm{m}^{2}$ para la matriz completa y 57,$06 ; 52,52 ; 48,03 ; 38,02 ; 37,65 \mathrm{~kJ} / \mathrm{m}^{2}$ con la inclusión de fibras de sisal, piassava, paja costera, mallow y yute, respectivamente. Luego, la superficie de fractura de los materiales compuestos se analizó con un microscopio para correlacionar los aspectos de fractura con las propiedades mecánicas.

Palabras clave: Fibras vegetales; Materiales compuestos; Ensayo de tracción; Prueba de impacto.

\section{Introduction}

The increase in the production of consumer goods and, consequently, the production of waste, offensive gases and nonrecyclable materials, as well as the increase in the global growth rate that harms the life of the planet as a whole is something easily observable. However, the concern with environmental preservation also increases and, as a consequence, the search for environmentally correct materials, whose manufacturing processes and even waste are increasingly less harmful (Marchi, 2022; Monteiro et al., 2011; Motas, 2021; Asyraf, 2020).

There is great worldwide interest in the development of new technologies that allow the use of products with less environmental impact and that meet the needs of industries. For this reason, the development of research with composite materials has increased considerably in recent years, since it allows the combination of properties of different materials, being able to promote a sustainable mentality in the most varied scopes of the productive chain of a particular product (Omrani; Menezes; Rohatgi, 2016; Reis 2021).

When it comes to meeting specific properties, composite materials stand out because, as they are obtained by mixing two or more materials, they have properties not found in each of the components individually. The reasons for its increasing use are due to its characteristic properties, such as high values of strength and rigidity and lightness (Dias, 2019; Souza, 2020; Peças, 2018).

Polymer composites are the most researched and used due to the large number of applications and a lower processing cost than other types (Santos, 2020). Among the polymeric matrices used for the production of composites, the polyester matrix has stood out due to its mechanical properties, low viscosity, high wettability and low cost. Unsaturated polyesters are extremely 
versatile in their properties and applications and have been a popular thermoset used as a polymer matrix in composites. They present some technical and economically interesting advantages, such as: dimensional stability, cold curing, possibility of using simple and cheap molds, in addition to good mechanical properties (Souza, 2020; Aziz et al., 2005).

The use of natural lignocellulosic fibers as reinforcement in composite materials is due to their being recognized as lowweight and low-cost materials, and their use as a replacement for traditional synthetic fibers, such as glass and aramid fibers, has been investigated, resulting in several possibilities in engineering applications (Adekomaya et al., 2017; Candido, 2017). They have relevant importance since they are renewable, biodegradable materials and have a non-carcinogenic nature, in addition, due to the versatility of these fibers, it allows them to be suitable for various purposes. (Asim et al., 2015; Simonassi, 2017; Hadi, 2021).

Fiber-reinforced composites can be classified according to fiber length into composites with continuous fibers (long fibers) and discontinuous fibers (short fibers) (Rajak, 2019), their mechanical behavior is influenced by several parameters, such as fiber volumetric fraction, fiber length, fiber-matrix adhesion, fiber orientation and stress transfer at the interface (Acosta, 2021). It can be used as a sustainable option in automobiles, aircraft interiors, civil construction, textiles, furniture, medicine and pharmaceuticals, domestic and personal care (Peças, 2018; Khalid, 2021; Neves, 2020). In research on the development of composite boards/panels, (Uppal 2019) evaluated the impact of the incorporation of $5 \mathrm{~mm}$ chopped sisal fiber mat on the mechanical behavior of polyester composites. The tensile, flexural and impact strengths of composites developed using chopped sisal fiber short mat (preform) were $45.87 \pm 3.2,102.29 \pm 9,33,954 \pm 5288 \mathrm{~J} \mathrm{~m}^{-2}$, respectively.

In this way, it is noted that the use of composite materials with the inclusion of natural plant fibers is a promising branch in the great area of materials science and engineering and the study of the properties of these materials is extremely important. Thus, the present study proposes to investigate the mechanical behavior of polyester matrix composites with the inclusion of vegetable fibers in terms of their flexural properties and to characterize these new materials in terms of the energy required for their rupture, contributing to the process of search for new sustainable, economically viable and technologically advanced materials.

\section{Methodology}

The methodology that guided this article is structuralist, according to Pereira et al. (2018). The studies were established from real data and experiments in Materials Engineering laboratories, based on mathematical models. The scientific product is represented and, finally, the result of the investigation is evidenced, related to the a priori information of nature, structured and correlated with the conditions and restrictions of Mechanical Engineering.

The systems established in mathematical models were implemented in computational language in order to minimize the error between the observed values and the estimated values of the related phenomena. This research benefits from the mechanism presented by Costa D. C. L. et al. (2020).

\subsection{Materials}

The plant fibers used were sisal (Agave sisalana), piassava (Attalea funifera Mart), raffia (Raphia vinífera), mallow (Urena lobata) and jute (Corchorus capsu-laris), all obtained in the commerce of the city of Belém-Pará-Brazil.

The polymer used for the production of composites was tere-phthalic unsaturated polyester (CrystaL type), produced by Centerglass Resins \& Fibras de vidro. The curing agent used was MEK peroxide in the proportion of $0.33 \%$ (v/v), following the procedure established by (RODRIGUES, 2008), who tested different proportions ( $\mathrm{v} / \mathrm{v}$ ) of MEK-P curing agents in unsaturated polyester resin, defining $0.33 \%$ as the proportion of longer workability with good mechanical properties. 


\subsection{Production of Composites}

The fibers were used in the way they were acquired, without surface treatment and under environmental conditions. Initially, they were cut to a length of $15 \mathrm{~mm}$ and randomly arranged inside the polymer matrix. The length of the fibers was determined through the ability of these fibers to be effective reinforcements within the matrix and also through the good efficiency of the fibers in accommodation, arrangement and ease of homogenization with the other constituents of the composites

The specimens were manufactured by hand molding using silicone molds and without pressure. The process started by treating the surface of the mold by applying a release agent to remove the part after the curing process. The mass fraction of each type of reinforcement used in the manufacture of the specimens of this research was defined by the volumetric capacity of the mold to accommodate the reinforcement without pressure or compaction and in the absence of the matrix. Then, each amount of reinforcement was duly weighed and the value of the mass obtained, converted into a mass fraction, was established as the reference for incorporation and workability for the manufacture of composites without pressure. From this reference value, the proportions to be used in the composites were prescribed, the values obtained for the mass fraction for the flexural test were $3.90 \%$ for Sisal, $14.82 \%$ for piassava, $6.65 \%$ for straw, 5.94\% Jute and 3.82\% Mallow. As for the Charpy impact test, the values obtained for mass fraction were 3.9\% for Sisal, $14.82 \%$ piassava, $6.65 \%$ raffia, 5.94\% Jute and 3.82\% Mallow. After curing, the specimens were removed from the molds and directed to the sanding stage, using sandpaper with a granulometry of 60 and 80 for iron in a Skill electric sander, to acquire predetermined dimensions and finishes, in accordance with me the patterns demonstrated by Figure 1.

Figure 1: Dimensions of specimens (a) Flexural test; (b) Charpy impact test.

(a)

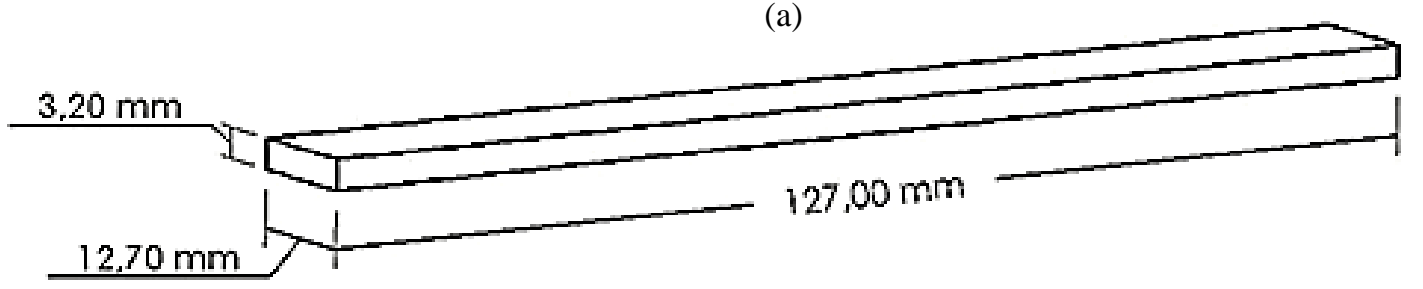

(b)

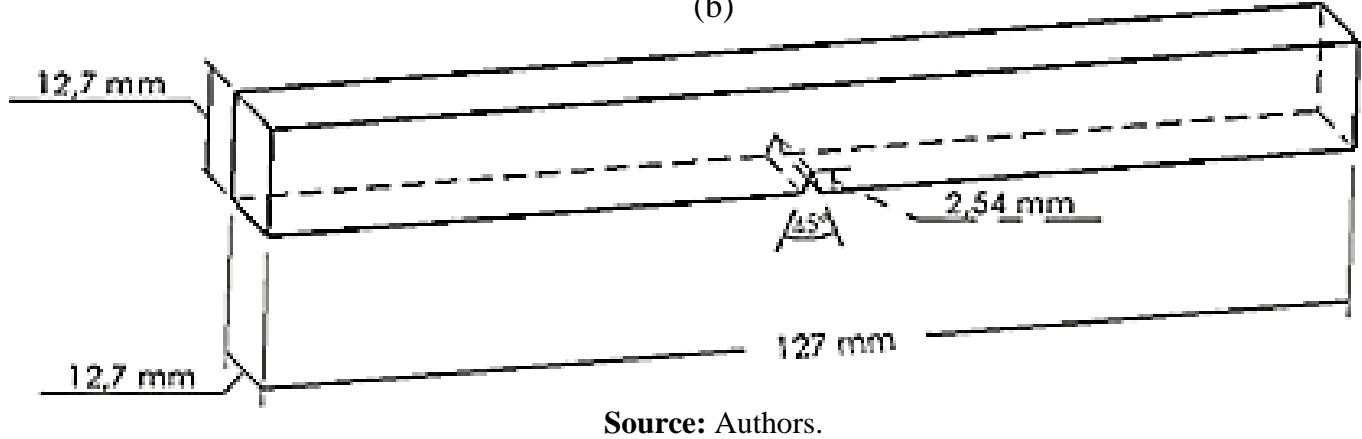

\subsection{Flexural Rehearsal}

The flexural tests at 3 (three) points of the materials under study in this work (matrixes and composites) were performed according to ASTM D 790-10 in an EMIC testing machine, model DL 500 with a cell of load with a capacity of $5 \mathrm{kN}$ and displacement speed of the machine head of $1.36 \mathrm{~mm} / \mathrm{min}$, carried out in the mechanical engineering laboratory on the campus of the Federal University of Pará in the city of Belém-Pará-Brazil. Based on the load-displacement curves and knowing the dimensions of the specimens, it was possible to determine the flexural strength of the composite $(\boldsymbol{\sigma})$ and the flexural modulus of elasticity $(\boldsymbol{E})$ according to Equation (1). 


$$
\sigma=\frac{3 P L}{2 B W^{2}}
$$

Where $\boldsymbol{P}$ is the maximum load reached, $\boldsymbol{L}$ is the span between the supports, $\boldsymbol{B}$ and $\boldsymbol{W}$ are the width and thickness of the specimens, respectively.

For the calculation of the modulus of elasticity in flexural $(\boldsymbol{E})$ it is determined by Equation (2).

$$
E=\frac{m L^{3}}{4 B W^{2}}
$$

Where $\boldsymbol{m}$ is the slope of the load-deflection curve.

\subsection{Charpy Impact Test}

The Charpy impact tests with notch of this work were carried out according to the procedures of the ASTM D 6110 standard in a Gunl Impact Testing Machine model WP410 pendulum with a working capacity of $150 \mathrm{Nm}$, hammer with a mass of $9.9 \mathrm{~kg}$, impact speed of $5.5 \mathrm{~m} / \mathrm{s}$, pendulum length of $840 \mathrm{~mm}$ and angle of fall of $150^{\circ}$. The Charpy impact strength on the fabricated specimens was calculated from Equation (3).

$$
E_{a b s}=\frac{W}{h \times b} \times 10^{3}
$$

Where $\boldsymbol{W}$ is the energy absorbed when breaking the specimens in $\boldsymbol{J}, \boldsymbol{h}$ is the thickness of the specimen in $m m$ and $\boldsymbol{b}$ is the width of the specimen in $\mathrm{mm}$.

\subsection{Microscopic Analysis}

After the mechanical flexural and impact tests, the fracture surfaces of each specimen were analyzed to verify the main failure mechanisms. The analyzes were performed using a Carl Zeiss optical microscope, model Stemi 508, with an AX-IO-CAM 105 Color camera attached.

\subsection{Computer Simulations}

One of the methodological strategies was performed using Computer Simulations. This step was performed in PYTHON language, in the IDE (Integrated Development Environment) Spyder 5.2.

For Costa D. C. L. et al. (2020), computer simulation is an essential strategy for this type of study. One of the main purposes is the delimitation of ideal values to the variables that model a phenomenon.

For Costa, H. A. de O. et al. (2021a), computer simulation allows the production of operational scenarios in complex systems, demonstrating the importance of the interdisciplinarity of academic knowledge of Mathematics, Physics and Computer Science, providing a modeling of engineering problems.

In Costa, H. A. de O. et al. (2021b), the computational simulation is presented for the execution of a model composed by the Genetic Algorithm (GA) and by the Particle Swarm Optimization (PSO), aided by parallel computing methods.

Costa D. C. L. et al. (2022), apply methods of Bio-Inspired Computing in computer simulations with the objective of estimating scenarios that establish a balance between the generation of electric energy and the preservation of the environment.

The computational modeling is based on Equations (1) and (2) and confirms the experiments carried out from the premises highlighted in Equation (3). The graphical representations of this methodology are shown in Figures 2 
and 3.

Figure 2 shows the variation of flexural strength of the composite in function of the thickness of the specimen.

Figure 2: Behavior of flexural strength of the composite.

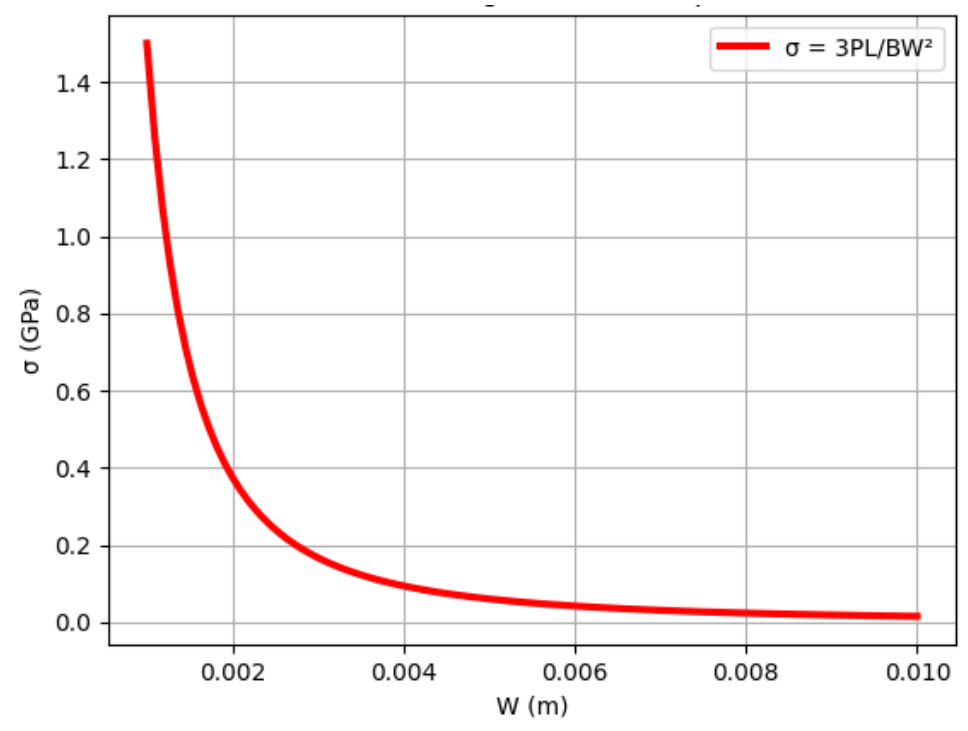

Source: Authors.

From the analysis of Figure 2, it can be noted that there is a strong decay of the flexural strength up to $2 \mathrm{~mm}$. From that point on, a reduction in the rate of this decay begins, indicating a stability in the flexural strength.

Figure 3 shows the variation of flexural modulus in function of the thickness of the specimen.

Figure 3: Behavior of flexural modulus.

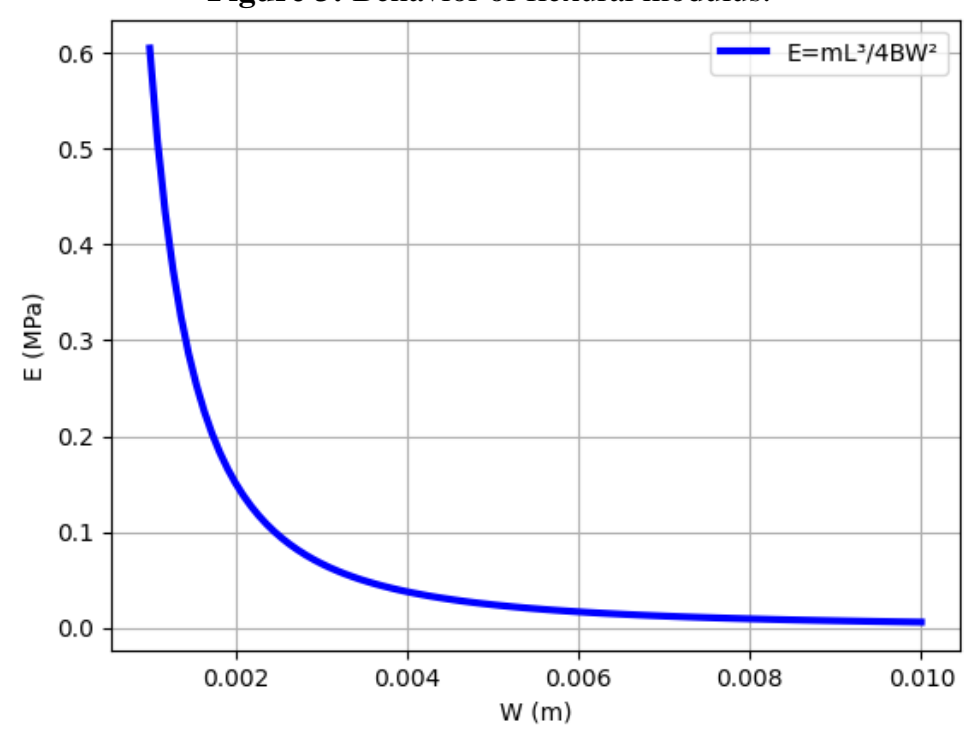

Source: Authors.

It can be seen, observing Figure 3, that there is an intense decay of the flexural modulus up to $2 \mathrm{~mm}$. From that point on, a reduction in the rate of this decay begins, indicating a stability in the flexural modulus. 


\section{Results and Discussion}

\subsection{Flexural strength}

Figure 4 shows the macroscopic aspects of the specimens after the three-point flexural test.

Figure 4: Flexural specimens in a) neat matrix and with the inclusion of fibers b) jute; c) mallow; d) piassava; e) raffia and f) sisal.

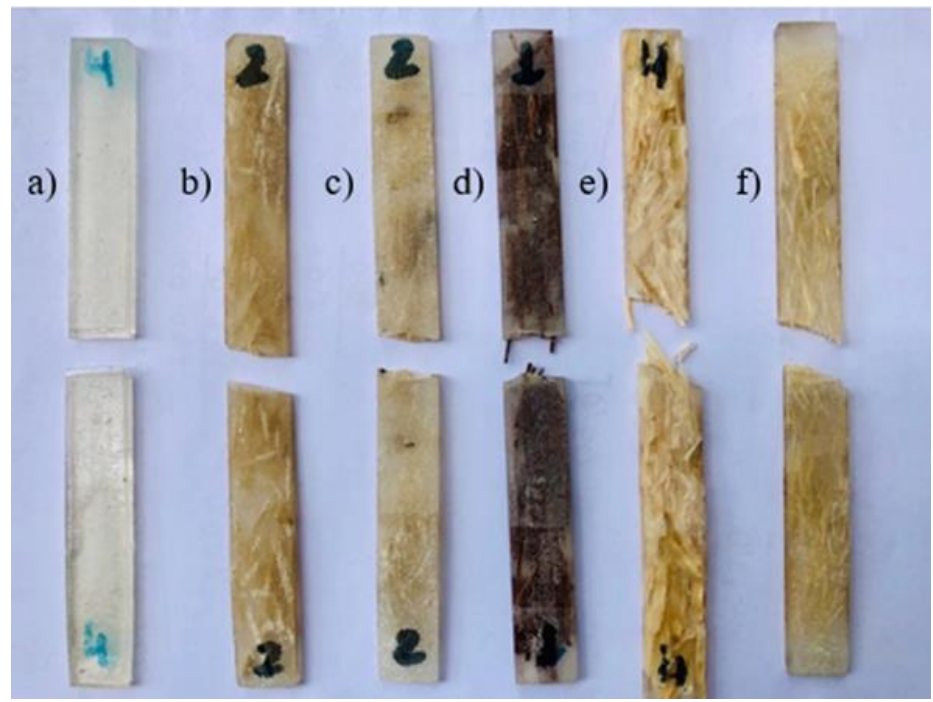

Source: Authors.

Initially, some preliminary data were obtained by the machine software, such as the relationship between the applied load $(\mathrm{N})$ as a function of the deflection $(\mathrm{mm})$ of the specimens during the test. These can be seen in Figure 5.

Figure 5: Characteristic curves of load vs. deflection of the polyester matrix with sisal, piassava, raffia, mallow and

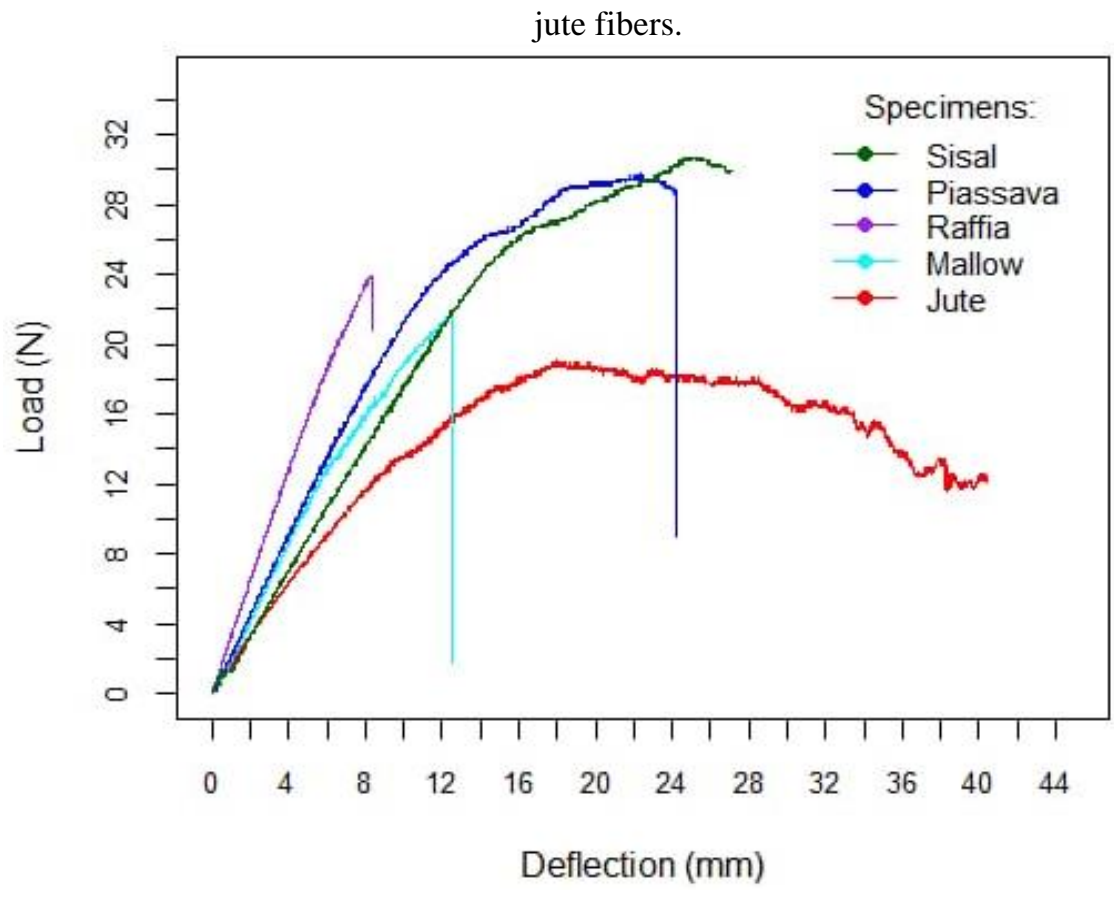

Source: Authors.

Analyzing the preliminary data, it is observed that the flexural curves of the polyester matrix with the addition raffia 
fibers from the coast and mallow have a linear behavior, typical of fragile materials, which when they reach the maximum point of resistance, break suddenly causing the applied load to drop, with the addition of sisal and jute fibers there was no sudden fracture and the load oscillates in its slow decrease, this is due to the effective resistance that the fibers offer to the propagation of cracks through the matrix, with the piassava fiber, the material obtained ductile behavior, but there was a sudden fracture. Table 1 shows the results found for each fiber incorporated.

Table 1: Results of the flexural strength test of neat matrix composites and with the inclusion of sisal, piassava, raffia, mallow and jute fibers.

\begin{tabular}{ccccc}
\hline Reinforcement & Load $(\mathbf{N})$ & $\begin{array}{c}\text { Average Flexural } \\
\text { Strength }(\mathbf{M P a})\end{array}$ & Flexural (mm) & $\begin{array}{c}\text { Flexural Modulus } \\
(\mathbf{G P a})\end{array}$ \\
\hline Neat matrix & $192.6( \pm 30.90)$ & $112.12( \pm 17.58)$ & $4.70( \pm 0.74)$ & $0.37( \pm 0.07)$ \\
Sisal & $31.40( \pm 1.78)$ & $35.21( \pm 1.74)$ & $26.66( \pm 3.50)$ & $15.81( \pm 2.75)$ \\
Piassava & $30.74( \pm 3.05)$ & $34.45( \pm 3.09)$ & $28.49( \pm 3.79)$ & $16.83( \pm 2.49)$ \\
Raffia & $23.94( \pm 2.89)$ & $27.29( \pm 3.12)$ & $9.26( \pm 1.31)$ & $5.61( \pm 0.85)$ \\
Mallow & $23.25( \pm 2.55)$ & $25.89( \pm 2.94)$ & $13.18( \pm 5.66)$ & $7.74( \pm 3.44)$ \\
Jute & $18.08( \pm 2.66)$ & $20.56( \pm 3.17)$ & $36.52( \pm 3.89)$ & $21.94( \pm 2.03)$ \\
\hline
\end{tabular}

Source: Authors.

For neat matrix composites, as shown in Table 1 above, it was observed, through the values provided, that the "initial" properties of the composite, that is, of the matrix without addition of fibers, was superior to all the values of the composites with the incorporation of vegetable fibers. Being $68.60 \%$ superior to sisal, $69.28 \%$ to piassava, $75.67 \%$ raffia, $76.91 \%$ to mallow and $81.67 \%$ to jute.

The results presented by the polyester matrix composites indicate that the addition of sisal, piassava, raffia, mallow and jute fibers can compromise the performance of the material when requested in flexural. We can consider that the decrease in these properties is due to a possible inefficient loading of the matrix, the fibers were not evenly distributed, resulting in a nonhomogeneous distribution of the applied forces, so instead of behaving as a reinforcement, it started to weaken the matrix, behaving as charge.

When considering the flexural modulus, the composites with the incorporation of vegetable fibers showed higher values of flexural modulus compared to pure polyester. The insertion of natural fibers with high modulus in thermoplastic polymer matrices (low modulus) can contribute to obtaining materials with differentiated properties. The modulus of elasticity in tensile and flexural are directly influenced by the high modulus of elasticity of the fibers (KLEMM et al., 1998).

Figure 6 presents the comparative graph that illustrates the mechanical behavior of polymeric composites with sisal, piassava, raffia, mallow and jute fibers.

Figure 6: Comparative graph that illustrates the mechanical behavior of polymeric composites with sisal, piassava, 
raffia, mallow and jute fibers.

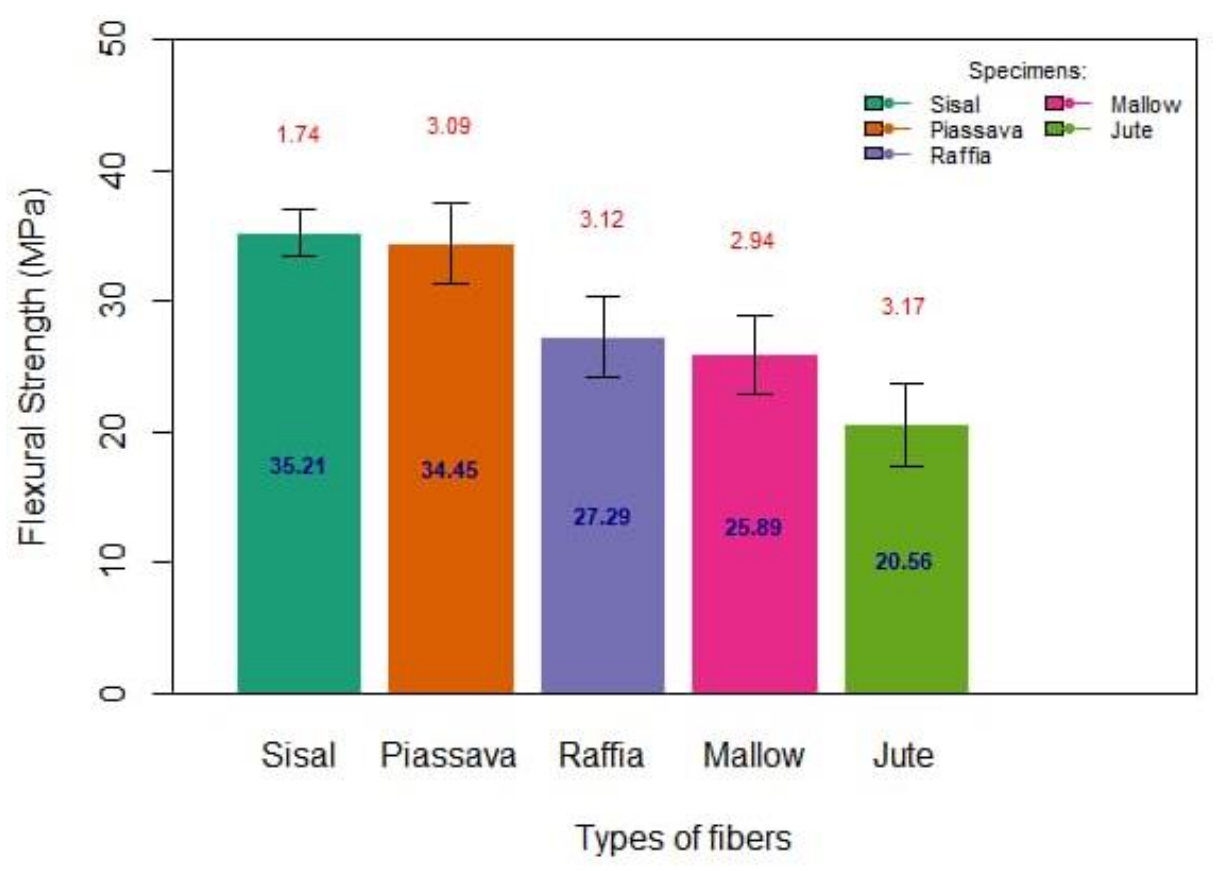

Source: Authors.

These low values obtained for composites with the inclusion of fibers of sisal, piassava, raffia, mallow and jute in polyester matrix can also be considered as a result of problems in the process of making the specimens, such as poor homogenization during the addition of catalyst to the resin, high concentration of air bubbles, in addition to the characteristics of the batch of resin supplied, incomplete curing of the composite and even problems related to the weak interface between hydrophobic matrix and hydrophilic fiber, making effective transfers of loads between them difficult. .

In terms of the internal behavior of the composite material, the "soft" and ductile fibers flex more easily along with the matrix, so the flexural strengths are close to each other, jute and mallow are the thinnest fibers, with the highest ratio of aspect, that is, they have smaller diameters, in the flexural test the fibers for having smaller diameters fail more easily and with that the resistance to flexural is lower. It must be taken into account that jute fibers are made from yarn, but the yarns fall apart during mixing with the resin for the manufacture of composites, and then they start to have geometric characteristics close to those of the fibers from mallow. In Table 2 it is possible to observe the flexural mechanical properties of the composites with the inclusion of plant fibers from this research and from other authors. 
Table 2: Flexural mechanical properties of composites with the inclusion of plant fibers from this research and from other authors.

\begin{tabular}{ccccc}
\hline Reinforcement & Fiber Length $(\mathbf{m m})$ & $\begin{array}{c}\text { Average Flexural } \\
\text { Strength }(\mathbf{M P a})\end{array}$ & $\begin{array}{c}\text { Flexural Modulus } \\
(\mathbf{G P a})\end{array}$ & Source \\
\hline Sisal & 15 & $35.21( \pm 1.74)$ & $15.81( \pm 2.75)$ & Authors \\
Piassava & 15 & $34.45( \pm 3.09)$ & $16.83( \pm 2.49)$ & Authors \\
Straw from Costa & 15 & $27.29( \pm 3.12)$ & $5.61( \pm 0.85)$ & Authors \\
Mallow & 15 & $25.89( \pm 2.94)$ & $7.74( \pm 3.44)$ & Authors \\
Jute & 15 & $20.56( \pm 3.17)$ & $21.94( \pm 2.03)$ & Authors \\
Jute & 15 & $57.58( \pm 5.88)$ & - & Ribeiro, 2015 \\
Sisal & 15 & $57.08( \pm 5.75)$ & - & Ribeiro, 2015 \\
\hline
\end{tabular}

Source: Authors.

The flexural test revealed that the addition of vegetable fibers impaired the mechanical strength of the materials. Considering exclusively the composites with the inclusion of vegetable fibers, the values found are lower than those found in the literature.

As a reference value, for the flexural strength of the neat matrix, (Simonassi, 2017), researching a polyester matrix composite, with reinforcement of ramie fibers, determined for the matrix without reinforcement, the value of 63 ( \pm 7 ) MPa. Ribeiro (2015), researching composites with the same matrix, but with various configurations of reinforcements, presented a value of flexural strength of the polyester resin without reinforcement of $75.88( \pm 7.57)$ MPa. Values that, with standard deviations, can be considered similar.

Angrizani et al. (2006), investigated the influence of sisal fiber length, with a content of $20 \%$ reinforcement/matrix in polyester matrix composite and determined that the flexural strength increased with increasing reinforcement length, being 53.4 $( \pm 7.8) \mathrm{MPa}$ for the length of $10 \mathrm{~mm}, 67.0( \pm 9.7) \mathrm{MPa}$ for the length of $30 \mathrm{~mm}$ and $80.4( \pm 6.6) \mathrm{MPa}$ for the length of $50 \mathrm{~mm}$.

A similar behavior occurred for the flexural modulus, which changed from $3.24( \pm 0.39)$ GPa for the $10 \mathrm{~mm}$ length, $3.68( \pm 0.42) \mathrm{GPa}$ for the $30 \mathrm{~mm}$ length and $4.22( \pm 0.36) \mathrm{GPa}$ for the $50 \mathrm{~mm}$ length. The elongation reduced from $3.6( \pm 0.2) \%$ in the composite with a length of $10 \mathrm{~mm}$ to $3.9( \pm 0.3) \%$ for the largest length studied, which was $50 \mathrm{~mm}$, a result consistent with the theoretical foundation that for greater modulus, greater rigidity.

In the work by Ribeiro (2015), the insertion of sisal or jute fibers, with $15 \mathrm{~mm}$ in length in the polyester matrix, did not add a gain in the flexural strength values, since in flexural stress loading, the strength depends largely on the interface reinforcement/matrix, as mentioned, and also due to the inherent defects of the natural fiber. Furthermore, in flexural, the specimens are subjected to complex mechanical stresses. This may also justify the greater propensity for premature rupture.

\subsection{Fractographic Aspect Flexural Test}

Figure 7 shows the fracture surface of an unreinforced polyester specimen after flexural test. 
Figure 7: Fracture aspects of an unreinforced polyester specimen.

(a)

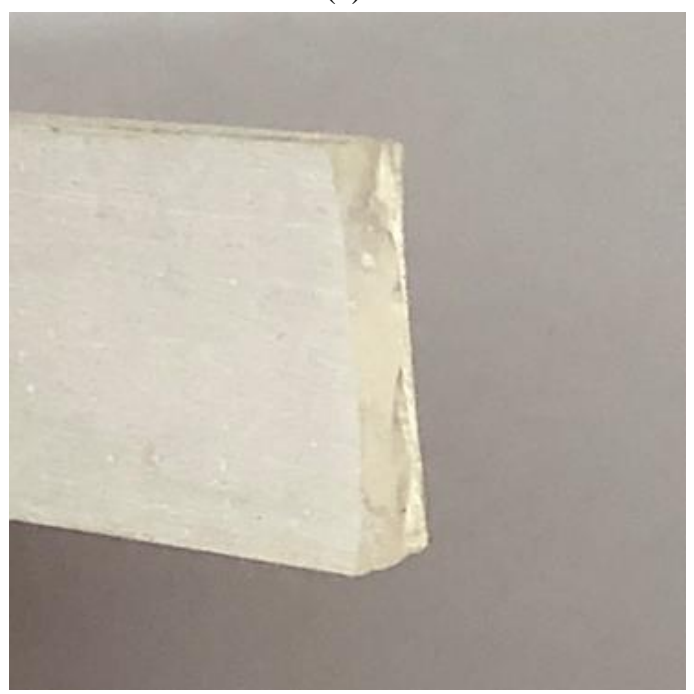

(b)

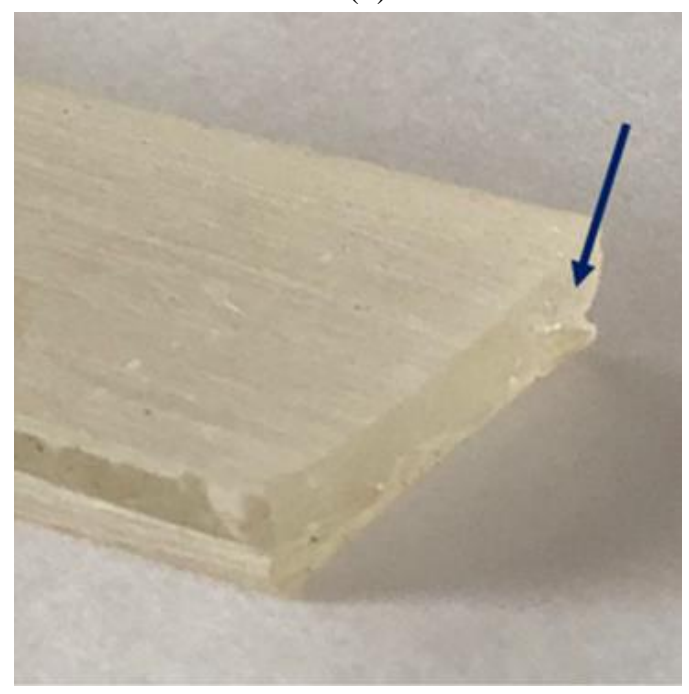

Source: Authors.

Figures 7(a) and 7(b) show the fracture surface of an unreinforced polyester specimen where we can see that the series of samples with $0.33 \%$ curing agent is practically free of bubbles, the amount of voids and porosity is not observed on the fractured surface, but the origin and direction of crack propagation are visible (arrow).

Figure 8 shows the fracture surface of a polyester specimen with sisal fibers after flexural test.

Figure 8: Fracture aspects of a polyester-polyester specimen with sisal fibers.

(a)

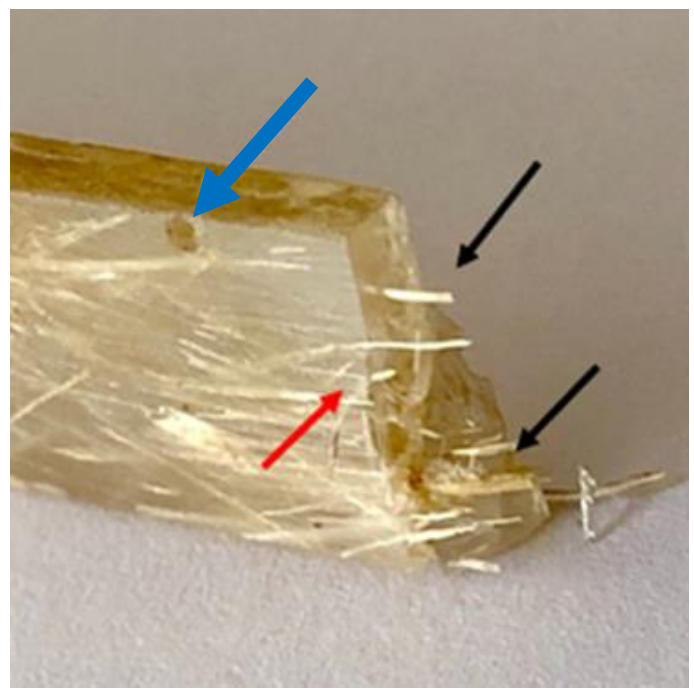

(b)

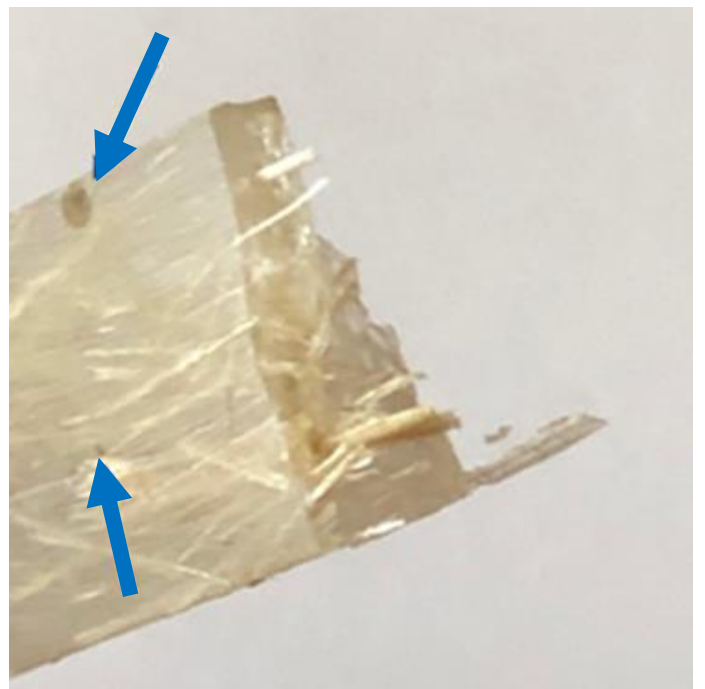

Source: Authors.

Figures 8(a) and 8(b) show the fracture surface of a polyester specimen with sisal fibers, which, among the composites made with vegetable fibers, was the one that obtained the best mechanical performance in the flexural test, verify - transverse cracking (red arrow), fiber rupture (black arrows) and voids/porosities from the manufacturing process (blue arrows).

Figure 9 shows the fracture surface of a polyester specimen with piassava fibers after flexural test. 
Figure 9: Aspects of fracture in a polyester sample with piassava fibers.

(a)

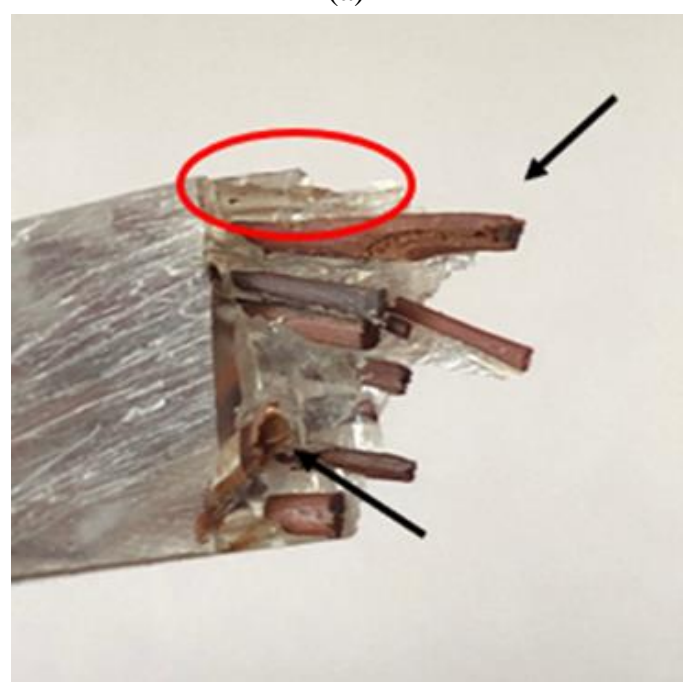

(b)

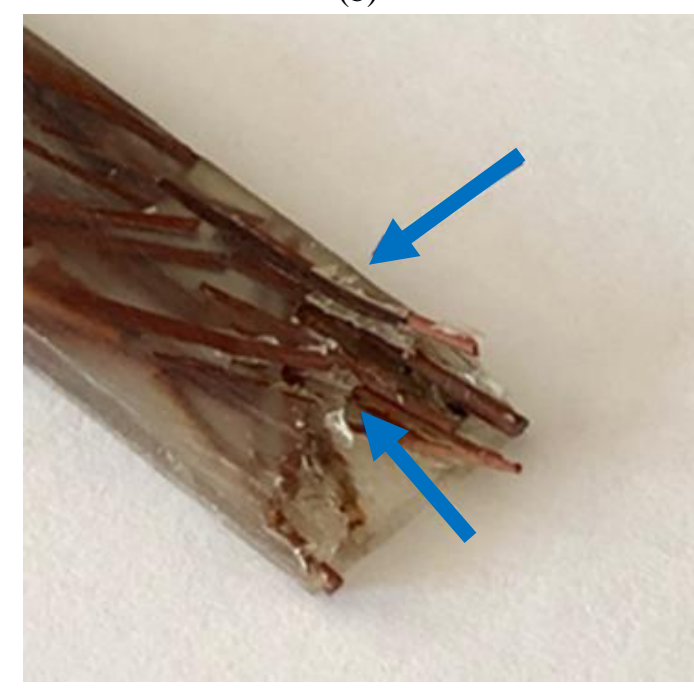

Source: Authors.

Figure 9(a) shows the fracture surface of a polyester specimen with piassava fibers, which among the composites manufactured with vegetable fibers, was the one that obtained the second best mechanical performance in the flexural test, verified if there was a complete fracture of the fibers during the flexural effort (black arrows) and the presence of pieces of the matrix that came loose during the test (red circle). In Figure 9(b) it can be seen that there was detachment of the matrix (blue arrows).

Figure 10 shows the fracture surface of a polyester specimen with shore straw fibers after flexural test.

Figure 10: Fracture aspects of a polyester specimen with shore straw fibers.

(a)

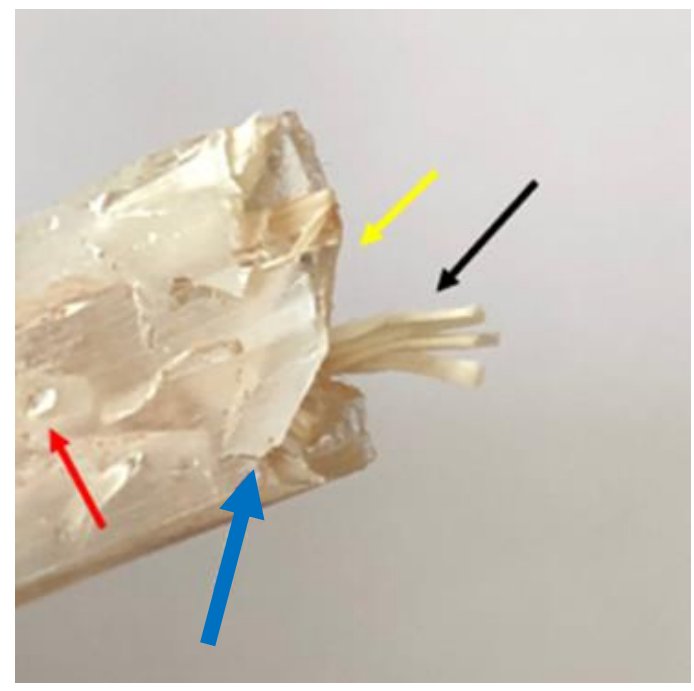

(b)

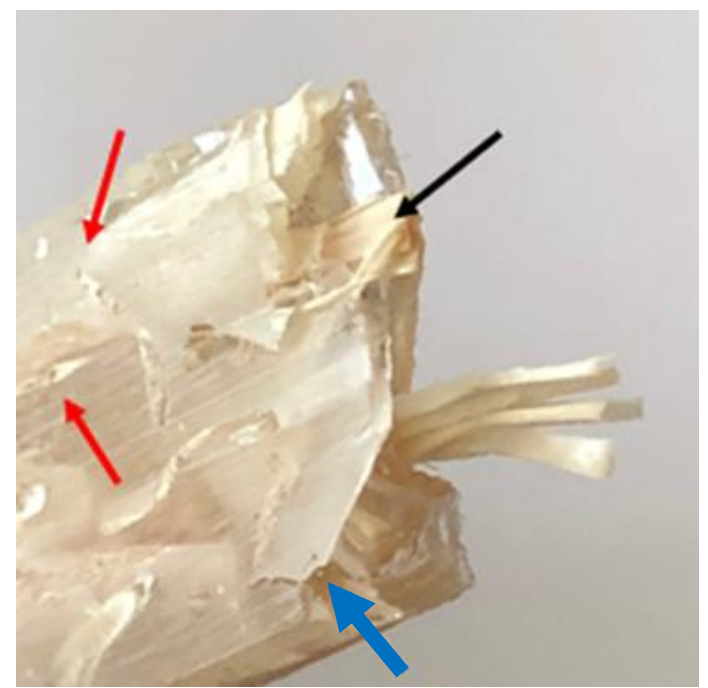

Source: Authors.

Figures 10(a) and 10(b) show the fracture surface of a polyester specimen with straw fibers from the costa, voids/porosities (red arrows) and transverse cracking (yellow arrow). Incorrect material specification, fiber and matrix content, 
inadequate percentage of voids, improper resin composition, incomplete resin cure degree, contaminants and high moisture retention may have contributed to premature failure of the material.

Figure 11 shows the fracture surface of a polyester specimen with mallow fibers after flexural test.

Figure 11: Fracture of a polyester sample with mallow fibers.

(a)

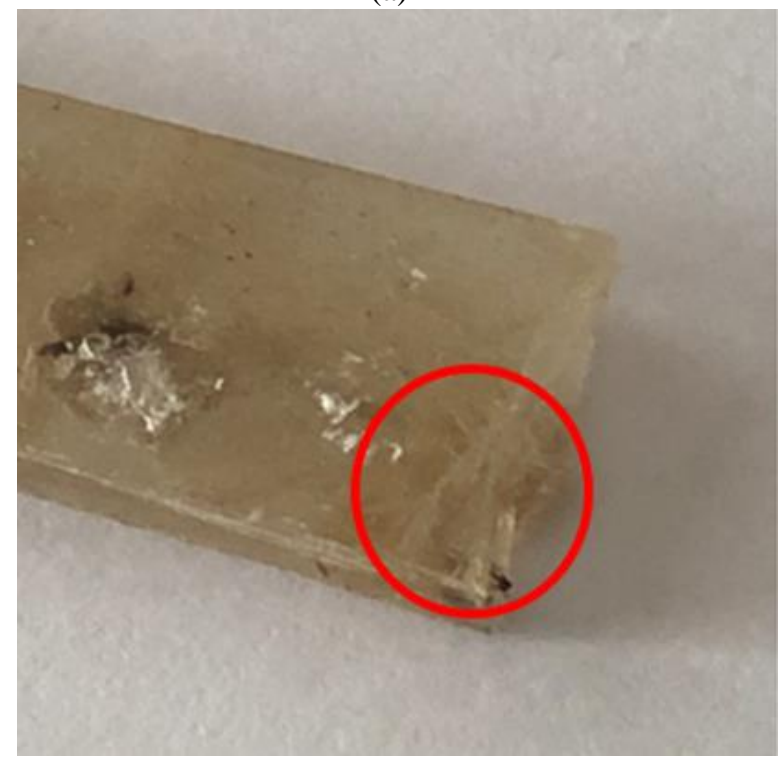

(b)

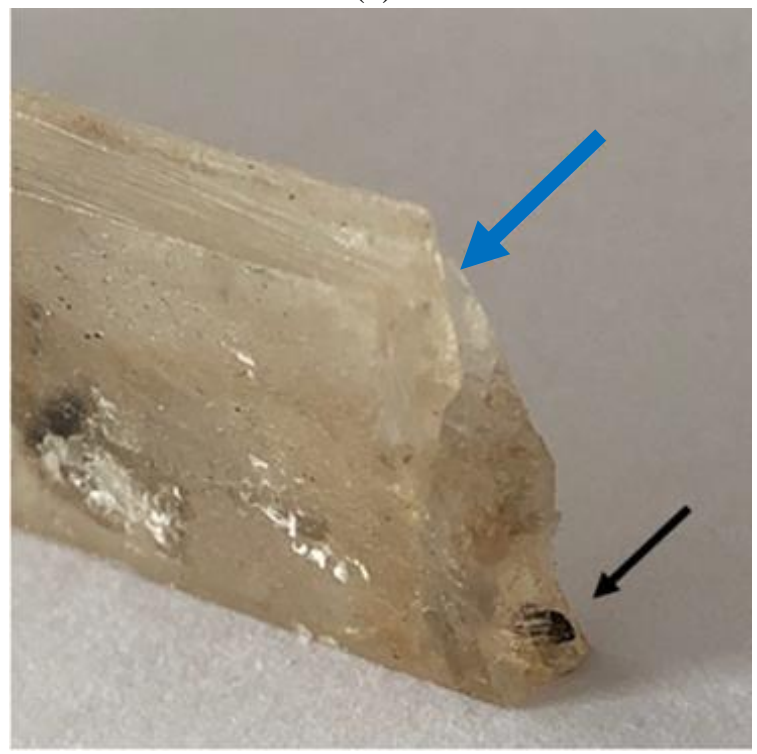

Source: Authors.

Figure 11(a) shows the fracture surface of a polyester specimen with mallow fibers, it is verified that it has pieces/parts of the matrix that came loose during the test (red circle). In Figure 11(b) it is possible to notice the complete fracture of the fibers during the flexural effort (black arrow) and the crack propagation direction indicated by the blue arrow can be verified.

Figure 12 shows the fracture surface of a polyester specimen with jute fibers after flexural test.

Figure 12: Fracture aspects of a polyester specimen with jute fibers.

(a)

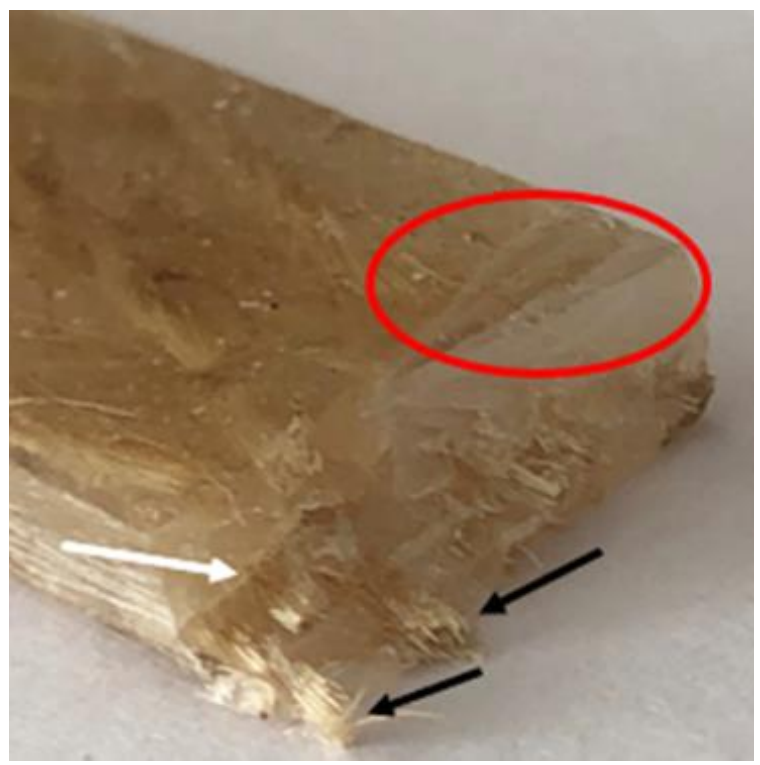

(b)

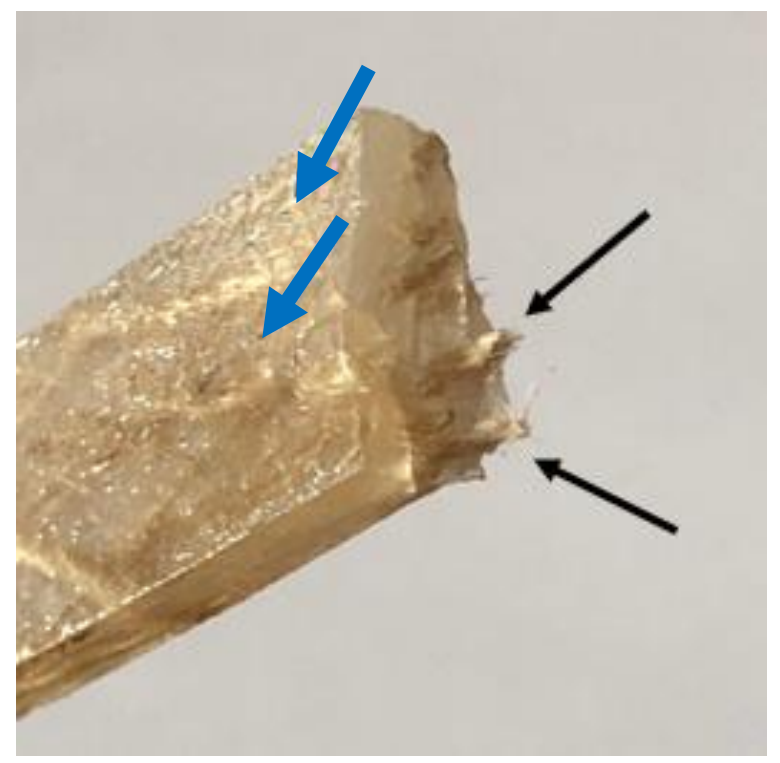

Source: Authors. 
Figure 12(a) shows the fracture surface of a polyester specimen with jute fibers, which among the composites manufactured with vegetable fibers, was the one that obtained the lowest mechanical performance in the flexural test, it appears that it presents pieces/parts of the matrix that came loose during the test (red circle), it is also possible to notice the complete fracture of the fibers during the flexural effort (black arrows) and the crack propagation direction is verified indicated by the white arrow. In Figure 12(b) we have the presence of voids/porosities (blue arrows) and the complete fracture of the fibers during the flexural effort (black arrows).

\subsection{Charpy Impact Toughness Test}

Figure 13 shows the macroscopic aspects of the specimens after the Charpy impact toughness test.

Figure 13: Impact test specimens in a) neat matrix and reinforced with fibers b) jute; c) mallow; d) piassava; e) raffia

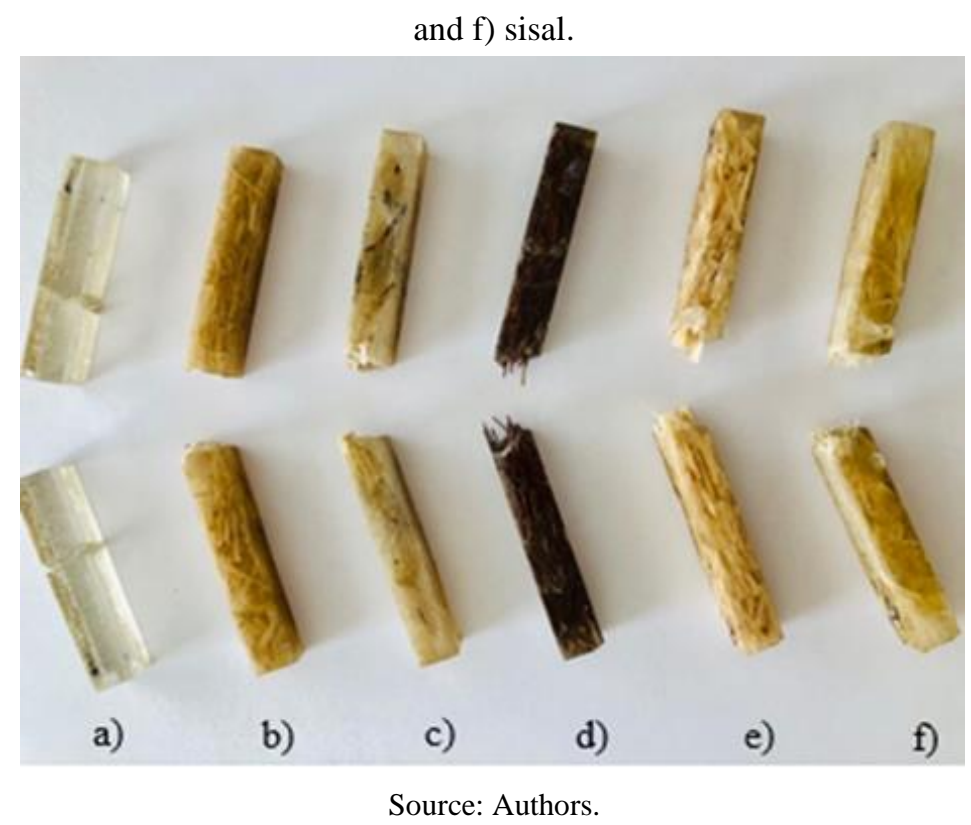

It can be seen in Figure 13 that in all samples the rupture occurred in the notch and that the incorporation of plant fibers resulted in a marked change in relation to the neat matrix, the rupture was not completely transverse. This indicates that cracks initiated in the notch propagate transversely through the polyester matrix, and when the crack reaches a fiber, failure will proceed across the interface. The mechanical characterization in relation to impact resistance of neat matrix composites and reinforced with sisal, piassava, straw, jute and mallow fibers are shown in Table 3. 
Table 3: Results of the Charpy impact toughness test of neat matrix and fiber-reinforced composites of sisal, piassava, raffia, jute and mallow.

\begin{tabular}{cccc}
\hline Reinforcement & Fiber Length $(\mathbf{m m})$ & Mass Fraction $(\%)$ & $\begin{array}{c}\text { Medium Impact } \\
\text { Resistance }\left(\mathbf{k J} / \mathbf{m}^{2}\right)\end{array}$ \\
\hline Neat matrix & - & - & $31.50( \pm 3.26)$ \\
Sisal & 15 & 3.90 & $57.06( \pm 3.65)$ \\
Piassava & 15 & 14.82 & $52.52( \pm 3.19)$ \\
Raffia & 15 & 6.65 & $48.03( \pm 2.93)$ \\
Jute & 15 & 5.94 & $38.02( \pm 0.71)$ \\
Mallow & 15 & 3.82 & $37.65( \pm 1.81)$ \\
\hline
\end{tabular}

Source: Authors.

In the case of impact tests, it is difficult to predict whether a reinforced or an unreinforced polymer will have superior behavior, this is because the increase in stiffness with reinforcement will produce greater energy absorption for a given deformation of the sample when flexural occurs (before breaking), however, the fracture will occur at a lower deformation than that of an unreinforced sample due to the greater brittle character (De and White, 1996).

From the results shown in Table 3, there is an increase in strength for all composites with fibers in relation to the neat matrix, showing that the fibers acted as an effective reinforcement within the polymer matrix.

The composites made with the inclusion of sisal fibers obtained a superior mechanical performance in $44.8 \%$ to the neat matrix, the composites made with the inclusion of piassava fibers obtained a superior mechanical performance in $40.03 \%$, the composites made with the inclusion of fibers raffia obtained a superior mechanical performance in $34.42 \%$, the composites made with the inclusion of jute fibers obtained a superior mechanical performance in $17.15 \%$ and the composites made with the inclusion of mallow fibers obtained a superior mechanical performance by $16.34 \%$.

In Figure 14 we have the comparative graph that illustrates the mechanical behavior of the neat matrix and the polymeric composites reinforced with sisal, piassava, straw, jute and mallow fibers. 
Figure 14: Comparative graph illustrating the mechanical behavior of the neat matrix and polymeric composites reinforced with sisal, piassava, straw, jute and mallow fibers.

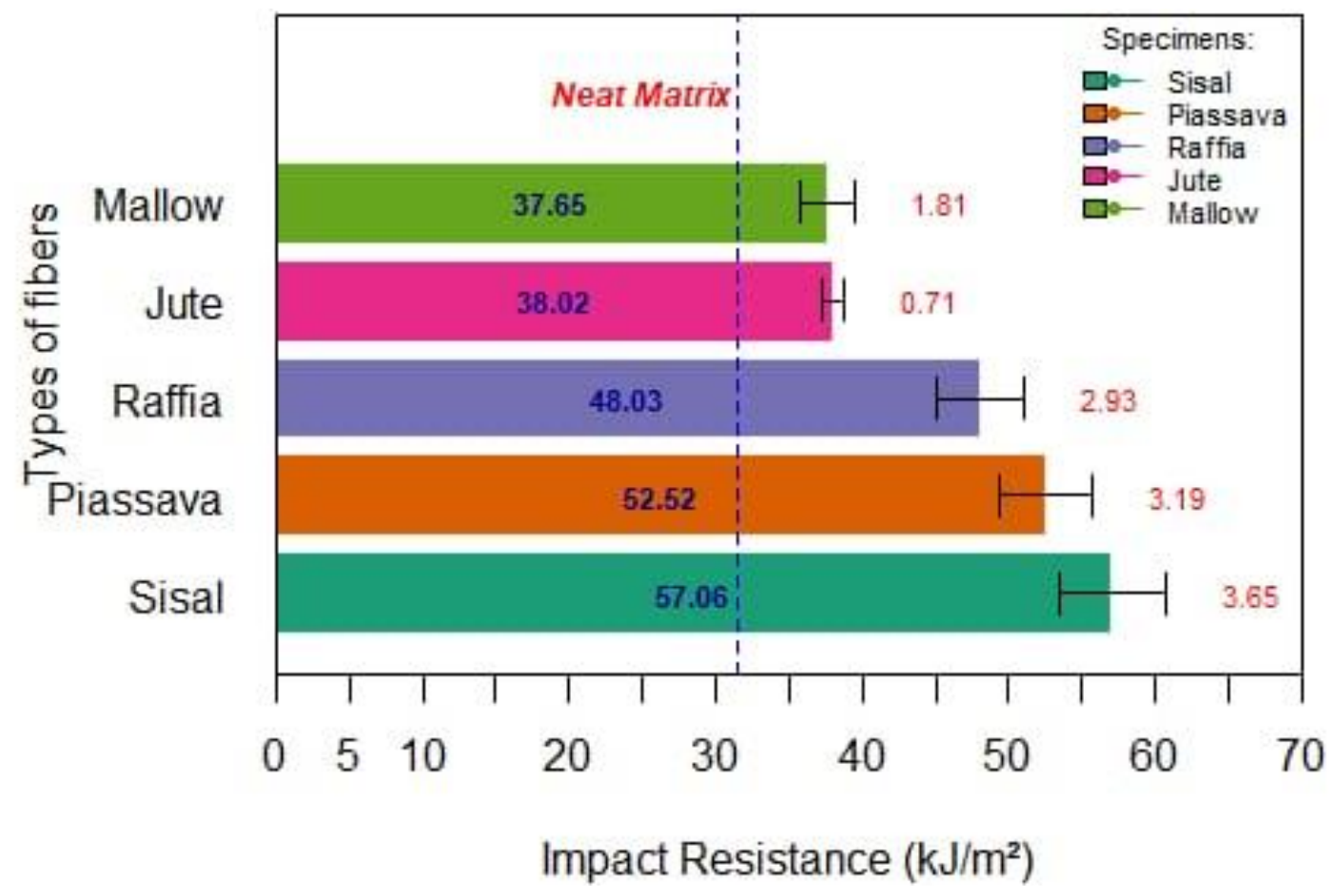

Source: Authors.

As studied by Costa (2016), the composites with sisal fibers obtained the best performance among the tested series, this may have occurred because the sisal fibers have better characteristics and properties than the mallow and jute fibers, such as their tensile strength is superior to the others, it has an improved or refined surface finish, compact constituent elements, without microfibril dismemberment, which can be essential for improving the impact resistance of the sisal fibers within the composites.

This result, in general, was already expected, since the reinforcement of fibers, both synthetic and natural, is known to increase the impact energy of composites with a polymer matrix (Fu et al., 1999). It was observed by (Fornari Junior, 2017) that the size, shape and surface of the plant fiber have an influence on the impact resistance property. The coupling agent has not improved and in most composites it even decreases the impact strength of the material. When the composite does not have a coupling agent, part of the impact energy can be lost in the transmission from the polymer matrix to the fiber, that is, at the fiberpolymer interface. This energy loss is attributed to the effects of displacement and friction, necessary to move the fiber of the polymer matrix. When the interaction between the two materials is weaker, that is, there is no presence of a coupling agent that improves the interaction of the materials, there is less cohesion between the fiber and the matrix, facilitating fiber displacement. This will promote or allow for greater frictional energy loss as impact energy is added to the material. During the transmission of impact energy, part of it is spent to displace or shear the matrix fiber, consuming an amount of impact energy.

In terms of the internal behavior of the composite, the fibers of larger diameters and massive appear as continuous elements inside the matrix and with that the energy for failure is greater, the crack will have to go around the fiber for the total fracture of the composite. material while the fibers of smaller diameter suffered fracture along the propagation of the crack more easily and with that the energy will be smaller for this effect, that is why the composites with fibers of jute and mallow present resistance to the impact so close.

The relatively low interface between a hydrophilic natural fiber and a hydrophobic polymeric matrix contributed to ineffective charge transfer from matrix to fiber. This feature allows the system to absorb more energy due to the flexibility of 
the fiber that slides out of the matrix, which amplifies the energy required for the rupture of the sample, since great energy must be spent in detaching the fibers, branching the crack and thus displacing it. those of the matrix (Monteiro et al., 2006).

In Table 4 it is possible to observe the mechanical properties in impact of the composites reinforced with vegetable fibers of this research and of other authors.

Table 4: Mechanical properties in impact of composites reinforced with vegetable fibers from this research and from other authors.

\begin{tabular}{ccccc}
\hline Reinforcement & $\begin{array}{c}\text { Fiber Length } \\
(\mathbf{m m})\end{array}$ & Mass Fraction (\%) & $\begin{array}{c}\text { Medium Impact } \\
\text { Resistance } \mathbf{( k J / \mathbf { m } ^ { 2 } )}\end{array}$ & Source \\
\hline Sisal & 15 & 3.90 & $57.06( \pm 3.65)$ & Authors \\
Piassava & 15 & 14.82 & $52.52( \pm 3.19)$ & Authors \\
Straw from Costa & 15 & 6.65 & $48.03( \pm 2.93)$ & Authors \\
Jute & 15 & 5.94 & $38.02( \pm 0.71)$ & Authors \\
Mallow & 15 & 3.82 & $37.65( \pm 1.81)$ & Authors \\
Sisal & 15 & 5.00 & $46.00( \pm 2.62)$ & Costa (2016) \\
Mallow & 15 & 5.00 & $36.00( \pm 1.47)$ & Costa (2016) \\
Jute & 15 & 5.00 & $32.64( \pm 1.78)$ & Costa (2016) \\
Sisal & 15 & 3.90 & $22.36( \pm 4.72)$ & Rodrigues (2008) \\
\hline
\end{tabular}

Source: Authors.

When compared to other studies, it appears that the results obtained in this research are superior to those found in the literature, compared to the study carried out by (Costa, 2016) which also used sisal, mallow and jute fibers, this research obtained a superior result of $19.39 \%$ for the composite made with the inclusion of sisal fibers, $4.39 \%$ for the composite made with the inclusion of mallow fibers and $14.16 \%$ for the composite made with the inclusion of jute fibers.

Rodrigues (2008) researching a polyester matrix composite reinforced with sisal fibers with lengths of 5, 10 and $15 \mathrm{~mm}$, showed that the Charpy impact strength of the neat matrix was $22.48( \pm 0.65) \mathrm{kJ} / \mathrm{m}^{2}$ and for composites with sisal fiber reinforcements, the impact strength was $16.84( \pm 2.94) \mathrm{kJ} / \mathrm{m}^{2}, 18.56( \pm 5.53) \mathrm{kJ} / \mathrm{m}^{2}$ and $22.36( \pm 4.72) \mathrm{kJ} / \mathrm{m}^{2}$ for fiber lengths of 5,10 and $15 \mathrm{~mm}$, respectively, with mass fractions of $5.41 \%, 4.87 \%$ and $3.90 \%$, respectively.

\subsection{Fractographic Aspect Charpy Impact Test}

Figure 15 shows the fracture surface of a non-reinforced polyester specimen after the Charpy impact test.

In Figure 15(a) we can see that the region demarcated by a rectangle indicates the region of high plastic deformation caused by the hammer impact at the time of the test.

In Figure 15(b) it can be seen that the fracture surface generated is practically flat and presents radial striations that indicate the origin of the crack, these characteristics, eminently of brittle fracture, with crack propagation in an unstable way, the black arrow indicates the crack propagation direction and the white arrows indicate the radial striations characteristic of brittle fracture. 
Figure 15: Fracture aspects of an unreinforced polyester specimen.

(a)

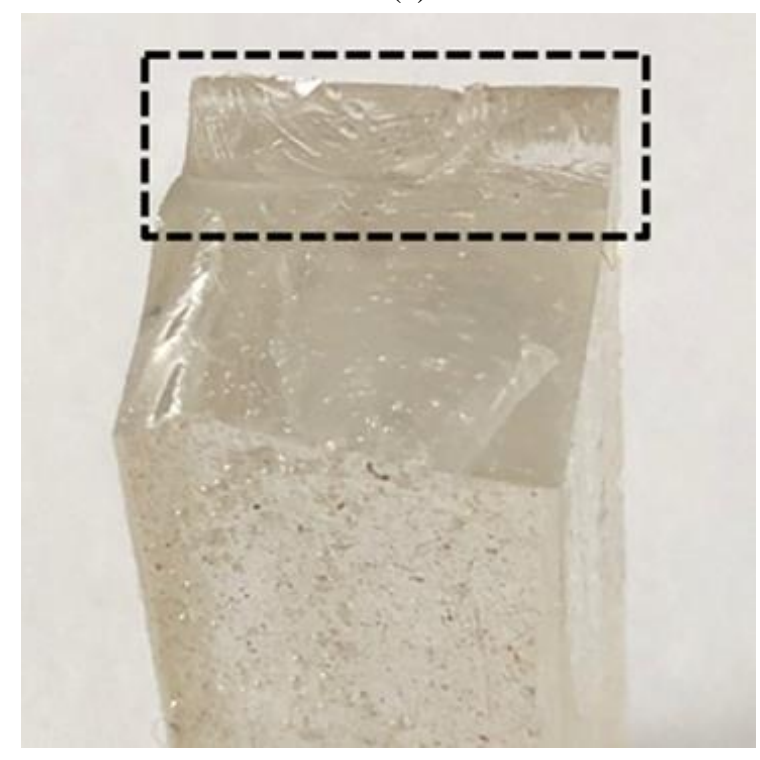

(b)

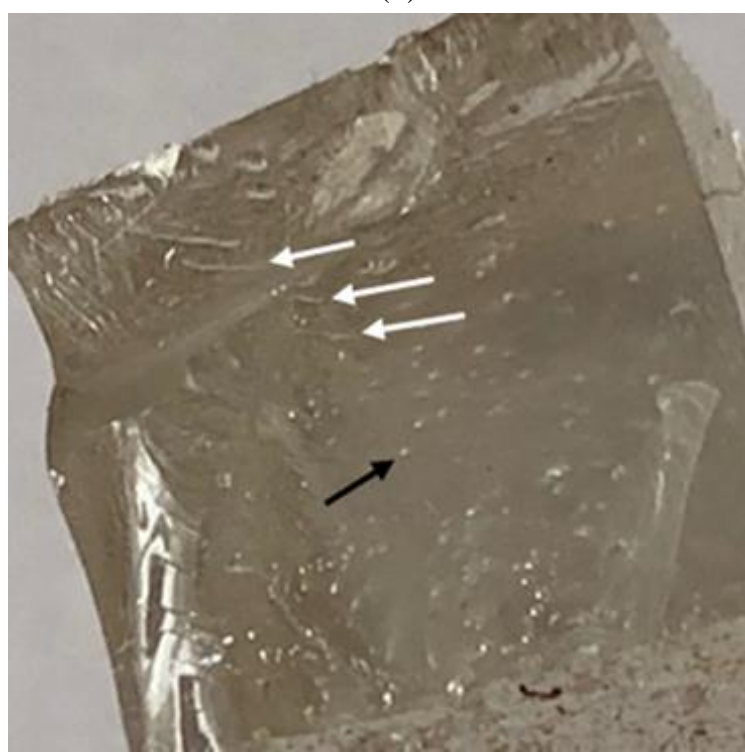

Source: Authors.

Figure 16 shows the fracture surface of a polyester specimen with sisal fibers after the Charpy impact test.

Figure 16: Fracture aspects of a polyester specimen with sisal fibers.

(a)

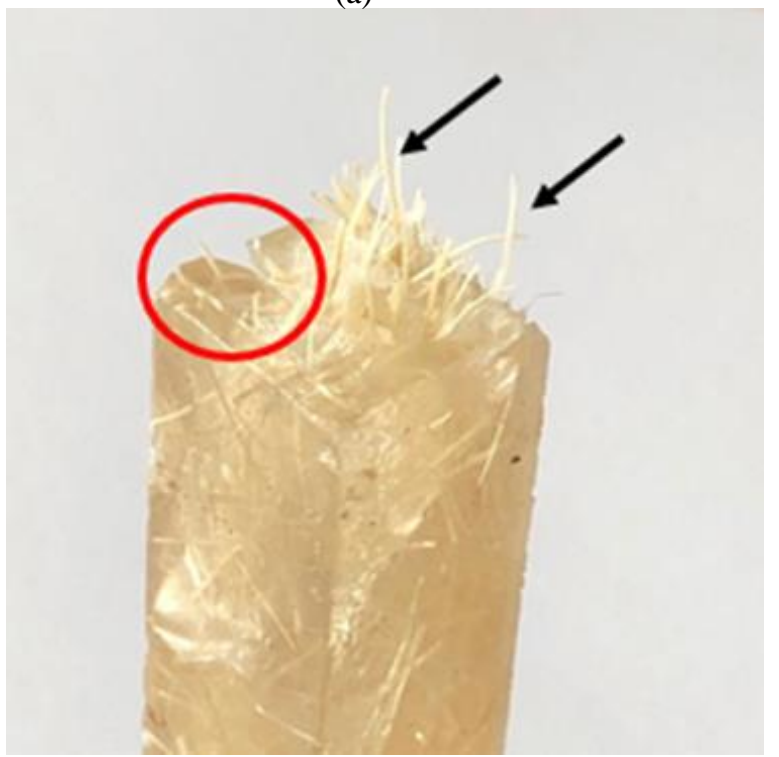

(b)

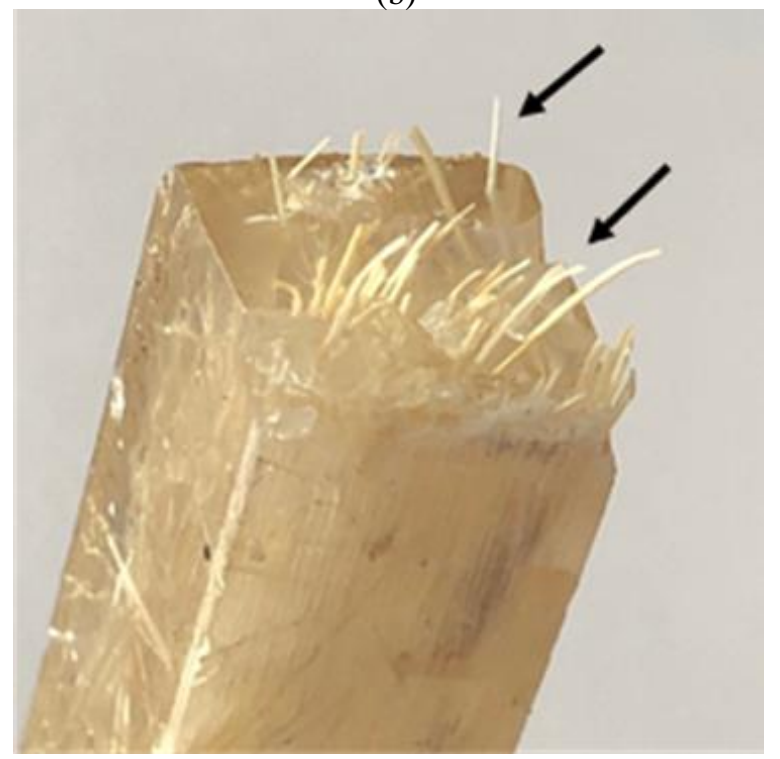

Source: Authors.

Figure 16(a) shows the fracture surface of a polyester specimen with sisal fibers which, among the composites manufactured with vegetable fibers, was the one that obtained the best mechanical performance in the Charpy impact toughness test, it is verified that it presents pieces/parts of the matrix that came loose during the test (red circle), in Figures 16(a) and 16(b) it is noted that there was a predominance of fibers pull out from the matrix, that is, the pull out, thus increasing the impact energy and consequently its resistance (black arrows).

Figure 17 shows the fracture surface of a polyester specimen with piassava fibers after the Charpy impact test. 
Figure 17: Fracture aspects of a polyester specimen with piassava fibers.

(a)

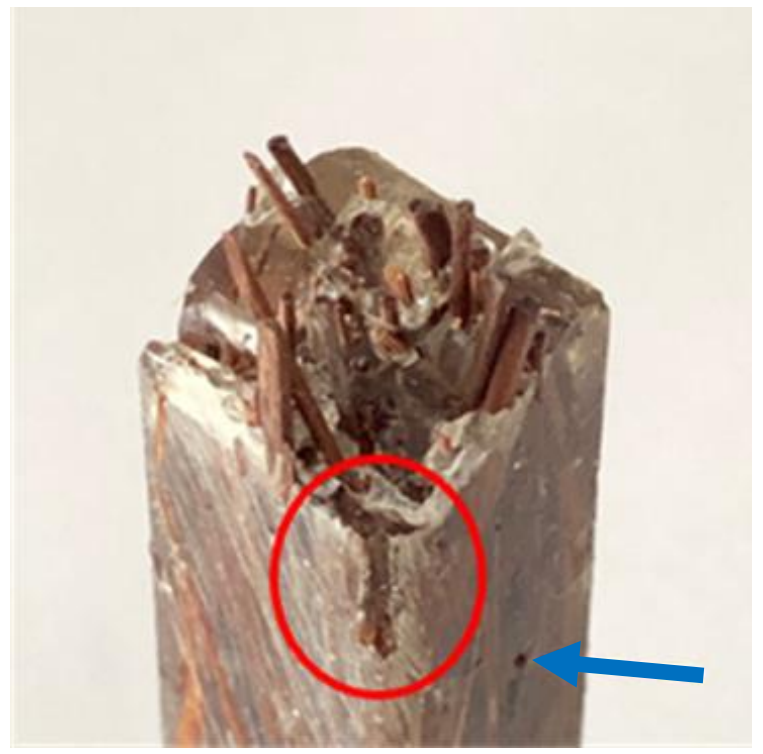

(b)

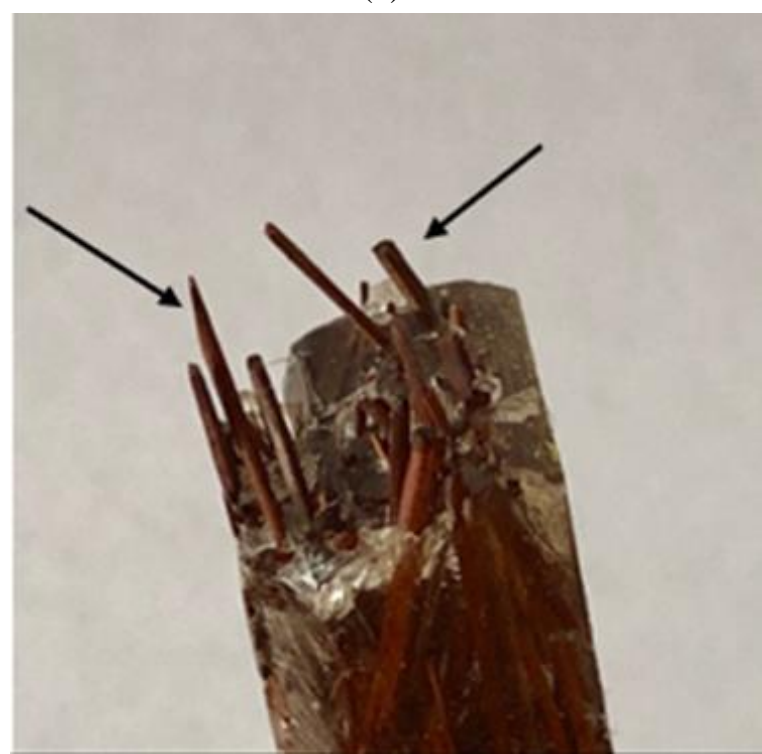

Source: Authors.

Figure 17(a) shows the fracture surface of a polyester specimen with piassava fibers, which, among the composites made with vegetable fibers, was the one that obtained the second best mechanical performance in the Charpy impact toughness test, verifies it can be seen that it has pieces/parts of the matrix that came loose during the test (red circle) and voids from the material manufacturing process (blue arrow). In Figure 17(b) it can be seen that there was a pull out and detachment of the matrix fibers (black arrows), elements that increase the impact resistance of the composites.

Figure 18 shows the fracture surface of a polyester specimen with shore straw fibers after the Charpy impact test.

Figure 18: Fracture aspects of a polyester specimen with shore straw fibers.

(a)

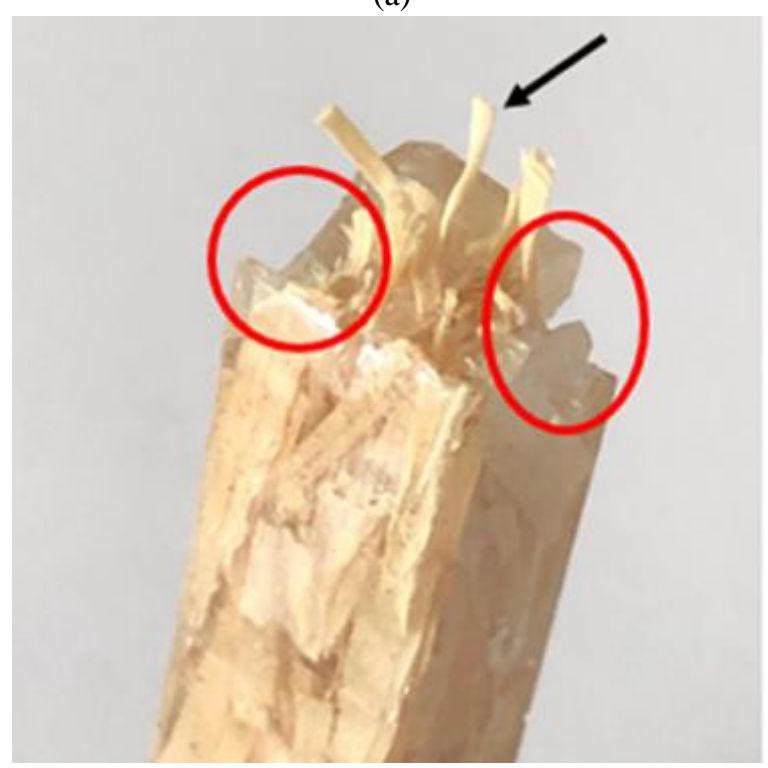

(b)

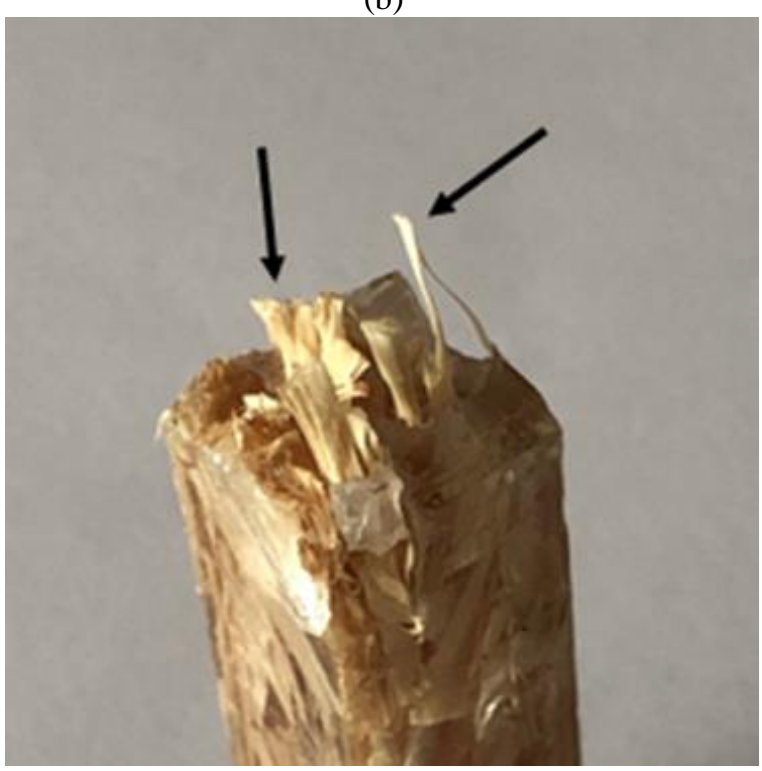

Source: Authors. 
Figure 18(a) shows the fracture surface of a polyester specimen with straw fibers from the costa, it is verified that, as in the other manufactured series, it also presents pieces/parts of the matrix that came loose during the test (red circle). In Figures 18 (a) and 18(b) it is possible to observe that there was a pull out and detachment of the matrix fibers (black arrows).

Figure 19 shows the fracture surface of a polyester specimen with jute fibers after the Charpy impact test.

Figure 19: Fracture aspects of a polyester specimen with jute fibers.

(a)

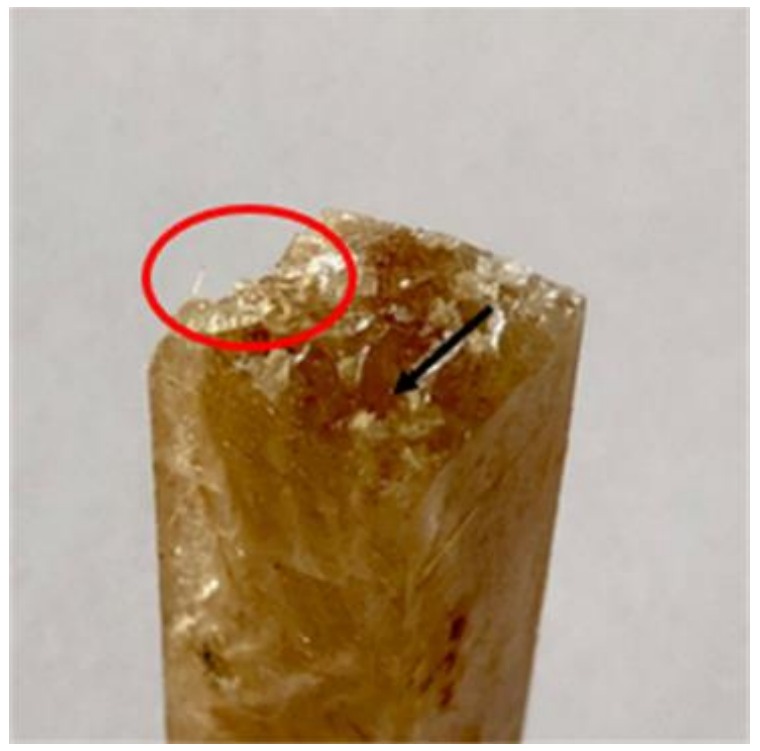

(b)

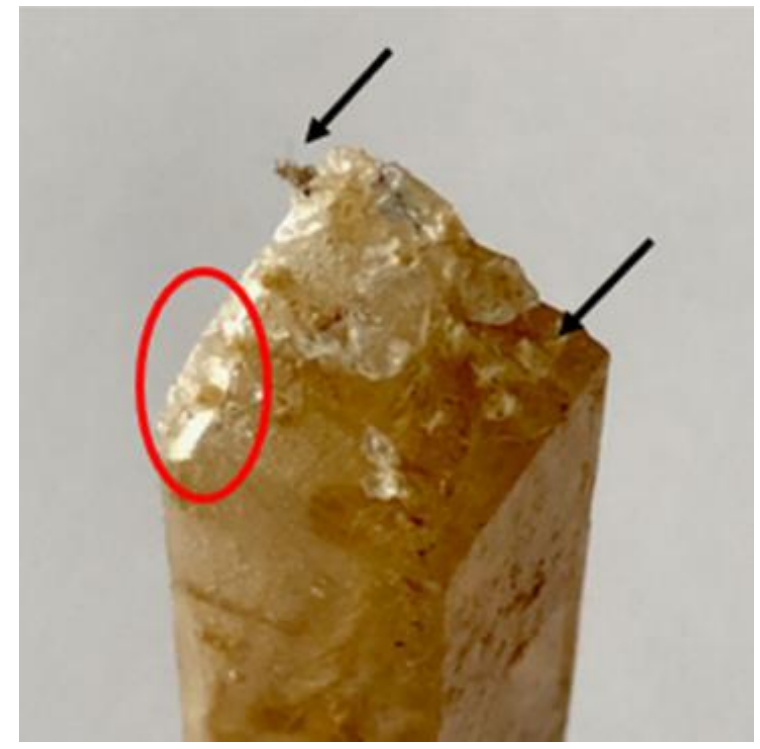

Source: Authors.

In Figures 19(a) and 19(b) we can observe the presence of pieces of the matrix that came loose during the test (red circle) and it is also observed that some fibers were separated from the matrix and others were broken during the impact (black arrows).

Figure 20 shows the fracture surface of a polyester specimen with mallow fibers after the Charpy impact test. 
Figure 20: Fracture aspects of a polyester specimen with mallow fibers.

(a)

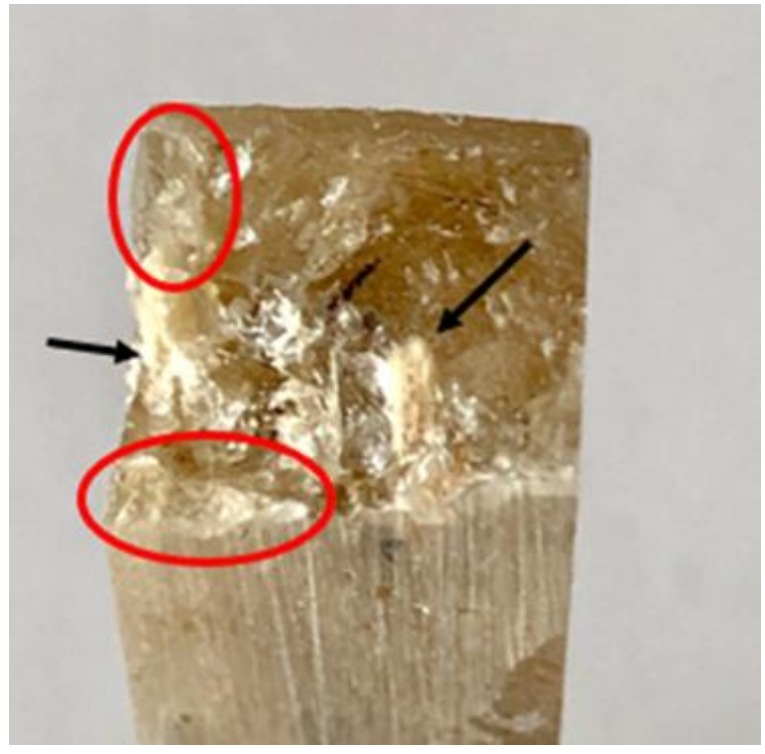

(b)

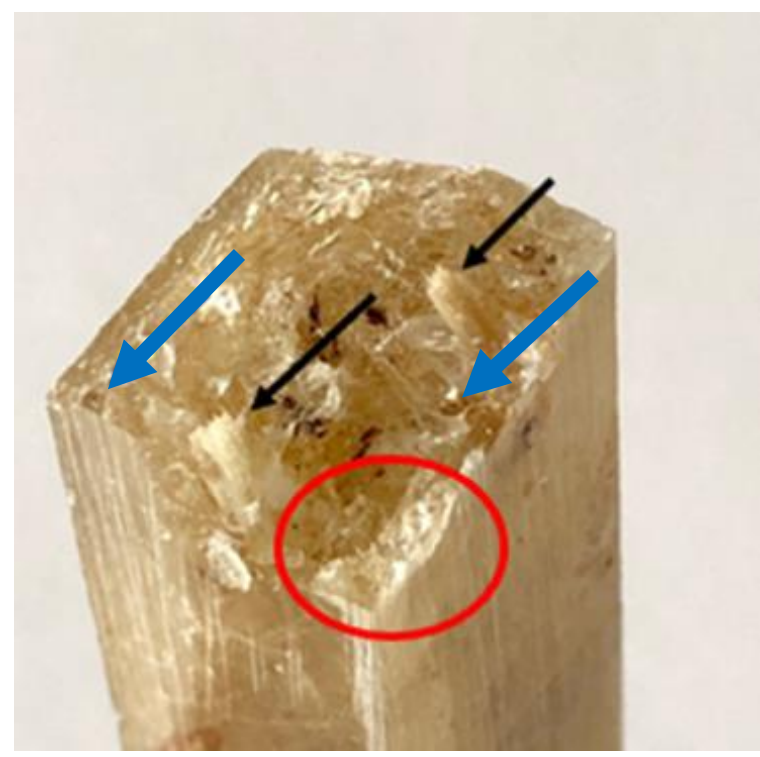

Source: Authors.

Figure 20(a) shows the fracture surface of a polyester specimen with mallow fibers, which among the composites manufactured with vegetable fibers, was the one that obtained the lowest mechanical performance in the Charpy impact toughness test, we have the presence of pieces/parts of the matrix that came loose during the test (red circle) and it is verified that there was a pull out and detachment of the matrix fibers (black arrows). In Figure 20(b) we also have the presence of pieces of the matrix that came loose during the test (red circle), fibers removed from the matrix (black arrows) and the presence of voids inside the composite, probably due to the greater difficulty in elimination of these caused by the insertion of the reinforcement (blue arrows).

\section{Final Considerations}

The methodology for manufacturing polymeric composites with the inclusion of short fibers of sisal, piassava, straw, mallow and jute used proved to be satisfactory, once the specimens were made, it was possible to test them according to the ASTM D standard. 790 in order to carry out the flexural tests and according to ASTM D 6110, in order to carry out the impact tests.

For the flexural tests, the mechanical properties found are inferior in comparison with those existing in the literature. The study of the flexural strength of polyester matrix composites with the inclusion of sisal, piassava, raffia, mallow and jute fibers revealed that when fibers were added to the matrix, the flexural strength values decreased. The decrease in strength may be associated with poor adhesion between the fiber and the matrix, which leads to a weak interface. When considering the flexural modulus, the composites showed higher values of flexural modulus in relation to pure polyester, since they are directly influenced by the high modulus of elasticity of the fibers.

As for the impact tests, it was possible to obtain coherent mechanical properties compared to those in the literature. There is a significant increase in energy absorbed in the Charpy impact tests with the incorporation of sisal, piassava, straw, jute and mallow fibers into a polyester matrix composite. The weak interface between the plant fibers and the polyester matrix contributes significantly to increasing the impact energy by altering the path of cracks in the composite. Most of this increase in toughness is apparently due to the low risk of fiber/matrix interfacial shear. This results in a higher absorbed energy as a 
consequence of a longitudinal propagation of the cracks along the interface, which generates larger areas of rupture, compared to a transverse fracture.

The fractographic study was efficient in determining the dominant failure mechanisms in each manufactured composition, giving us indications of the procedures to be adopted in the processing of composites to improve the mechanical properties.

As proposals for the continuity of this research, the authors of this article are dedicated to: performing chemical treatments on plant fibers in order to improve their properties; manufacture and analyze the properties of composite materials by varying the length of different types of fibers, verifying their influence on the properties; replace the polyester resin with other matrices to verify the mechanical behavior.

All these proposals can be simulated computationally, which will allow the recognition of patterns and optimize the results. Such strategies have the prospect of being implemented through the use of Artificial Intelligence, such as Artificial Neural Networks (ANN), Genetic Algorithm (GA) and Particle Swarm Optimization (PSO).

These strategies, based on Bio-Inspired Computing, will be able to provide information that enable the reduction of operational, energy and input costs, optimizing results.

\section{Acknowledgments}

The authors thank the following Brazilian agencies for supporting this investigation: CNPq, CAPES, UFPA and IFPA for providing research facilities and for their support of this manuscript. And to the Gradient Mathematical Modeling and Computer Simulation research group - $\mathrm{GM}^{2} \mathrm{SC}$, for their collaboration in scientific improvement.

\section{References}

Acosta, R.; Calle Trujillo, G.; Marulanda Arévalo, J. L. (2021). Synthesis and mechanical behavior of composite material reinforced with Guadua fiber and with a polyurethane or polyester matrix. BioResources. 16 (4), 8049-8059. https://doi.org/ 10.15376/biores.16.4.8049-8059.

Adekomaya, O.; Jamiru, T.; Sadiku, R.; Huan, R. (2017). Negative impact from the application of natural fibers. Journal of clean production. 143, 843-846. https://doi.org/ 10.1016/J.JCLEPRO.2016.12.037.

American Society for Testing and Materials. ASTM D 790. (2010). Standard Test Method for Flexural Properties of Unreinforced and Reinforced Plastics and Electrical Insulating Materials. Philadelphia: ASTM.

American Society for Testing and Materials. ASTM D 6110. (2010). Standard Test Methodfor Determining the Charpy Impact Resistance of Notched Specimens. Philadelphia: ASTM.

Angrizani, C. C.; Zattera, A. J.; Freire, E.; Santana, R. M. C. (2006). Influência do comprimento da fibra de sisal e do seu tratamento químico nas propriedades de compósitos com poliéster. In: $17^{\circ} \mathrm{CBECiMat} \mathrm{-} \mathrm{Congresso} \mathrm{Brasileiro} \mathrm{de} \mathrm{Engenharia} \mathrm{e} \mathrm{Ciência} \mathrm{dos} \mathrm{Materiais.} \mathrm{Foz} \mathrm{do} \mathrm{Iguaçu,} \mathrm{PR,} \mathrm{Brasil.}$

Asim, M.; Abdan, K.; Jawaid, M.; Nasir, M.; Dashtizadeh, Z.; Ishak, M. R.; Enamul, M. H. (2015). A Review on Pineapple Leaves Fibre and Its Composites. Hindawi Publishing Corporation International Journal of Polymer Science. 1-16. https://doi.org/10.1155/2015/950567.

Asyraf, M. R. M.; Ishak, M. R.; Sapuan, S. M.; Yidris, N.; Ilyas, R. A.; Rafidah, M.; Razman, M. R.; Deng, Yulin. (2020). Potential Ap-plication of Green Composites for Cross Arm Component in Transmission Tower: A Brief Review. International Journal of Polymer Science. 1-15. https://doi.org/10.1155/2020/8878300.

Aziz, S.H.; Ansell, M.P.; Clarke, S.J.; Panteny, S.R. (2005). Modified polyester resins for natural fibre composites. Composites Science and Technology. 65(34), 525-535. https://doi.org/10.1016/j.compscitech.2004.08.005.

Candido, V.S.; Silva, A.C.R.; Simonassi, N.T.; Luz, F.S.; Monteiro, S.N. (2017). Toughness of polyester matrix composites reinforced with sugarcane bagasse fibers evaluated by Charpy impact tests. Journal of Materials Research and Technology. 6, 334-338. https://doi.org/10.1016/j.jmrt.2017.06.001.

Costa, D. C. L., Costa, H. A. de O., Castro, A. P. S., Cruz, E. C., Azancort Neto, J. L., \& Cruz, B. C. C. da. (2020). The dimensions of Mathematical and Computational Modeling prescribed to Environmental Management. Research, Society and Development, 9(10), e6939109013, https://doi.org/10.33448/rsdv9i10.9013.

Costa, D. C. L., Meneses, L. A. de, Lima, M. L. V. de, Costa, H. A. de O., Reis, A. C. F., Pinheiro, H. F. B., Costa, E. F. da., Silva, A. R. dos S. da., Reis, A. C. F., Raiol, F. M., \& Santos, R. C. P. dos. (2022). Thermoelectric generation with reduced pollutants made possible by bio-inspired computing. Research, Society and Development, 11(1), e7611124568. https://doi.org/10.33448/rsd-v11i1.24568 
Costa, D. S. (2016). Estudo da influência de resíduos gerados pela indústria de mineração nas propriedades de compósitos de matriz poliéster reforçados com fibras naturais. 229 f. Tese (Doutorado em Engenharia de Recursos Naturais da Amazônia) - Universidade Federal do Pará, Belém, Brasil.

Costa, H. A. de O., Costa, D. C. L., \& Meneses, L. A. de. (2021a). Interdisciplinarity Applied to the Optimized Dispatch of Integrated Electricity and Natural Gas Networks using the Genetic Algorithm. Research, Society and Development, 10(2), e42110212641, https://doi.org/10.33448/rsd-v10i2.12641.

Costa, H. A. de O., Gomes, L. L., \& Costa, D. C. L. (2021b). Genetic algorithm and particle swarm applied in electric system optimization. Research, Society and Development, 10(10), e166101018871, https://doi.org/10.33448/rsd-v10i10.18871.

De, S. K.; White, J. R. (1996). Short Fibre-Polymer Composites. Wood head, Publishing Limited England, pg 2, 3, $64,65$.

Dias, R.S.M.; Gomes, I.d.S.; Vilhena, E.S.; Pereira, L.C.O.; Lopes, C.E.P.; Vilhena, E.S.; Oliveira, A.B.S.; Ribeiro, M.M.; Silva, S.C.; Araújo, L.R.; Bitencourt Júnior, A.H.S.; Fujiyama, R.T. (2019). Fabricação de materiais compósitos sanduíche reforçados com fibra de jute e resíduos de madeira. Brazilian Journal of Development. 5, 6376-6384. DOI:10.34117/bjdv5n6-141.

Fu, S.; Lauke, B.; Mäder, E.; Hu, X.; Yue, C.Y. (1999). Fracture Resistance of Short Glass-Fiber-Reinforced and Short-Carbon-Fiber-Reinforced Poly-propylene under Charpy Impact Load and its Dependence on Processing. Journal of Materials Processing Technologies. 89, 501-507. https://doi.org/10.1016/S09240136(99)00065-5.

Fornari Junior, C. C. M. (2017). Fibras Vegetais para Compósitos Poliméricos. 1. ed. Ilhéus: Editus UESC. v. 1. 198p.

Hadi, A.E.; Hamdan, M.H.M.; Siregar, J.P.; Junid, R.; Tezara, C.; Irawan, A.P.; Fitriyana, D.F.; Rihayat, T. (2021). Application of Mi-cromechanical Modelling for the Evaluation of Elastic Moduli of Hybrid Woven Jute-Ramie Reinforced Unsaturated Polyester Composites. Polymers. 13, 2572. https://doi.org/10.3390/polym13152572.

Khalid, M.Y.; Al Rashid, A.; Arif, Z.U.; Ahmed, W.; Arshad, H.; Zaidi, A.A. (2021). Natural fiber reinforced composites: Sustainable materials for emerging applications. Results in Engineering. 11, 100263. https://doi.org/10.1016/j.rineng.2021.100263.

Klemm, D.; Philipp, B.; Heinze, T.; Heinze, U.; Wagenknecht, W. (1998). Comprehensive Cellulose chemistry. Weinheim: Wiley - VCH, v.1. 260.

Marchi, B.Z.; Oliveira, M.S.; Bezerra, W.B.A.; De Sousa, T.G.; Candido, V.S.; Da Silva, A.C.R.; Monteiro, S.N. (2021). Ubim Fiber (Geonoma baculífera): A Less Known Brazilian Amazon Natural Fiber for Engineering Applications. Sustainability. 14, 421. https://doi.org/10.3390/su14010421

Monteiro, S.N., Lopes, F.P.D.; Barbosa, A.P.; Bevitori, A.B.; da Silva, I.L.A.; Costa, L.L. (2011). Natural Lignocellulosic Fibers as Engineering Materials-An Overview. Metallurgical and Materials Transactions. A. 42, 2963-2974. https://doi.org/doi:10.1007/s11661-011-0789-6.

Monteiro, S.N.; Aquino, R. C. M. P.; Lopes, f. P. D.; D'almeida, J.R.M. (2006). Tenacidade ao entalhe por impacto Charpy de compósitos de poliéster reforçados com fibras de piassava. Matéria. Rio de Janeiro-RJ. 11 (3), 204-210. https://doi.org/10.1590/S1517-70762006000300006.

Motas, J.G.; Gorji, N.E.; Nedelcu, D.; Brabazon, D.; Quadrini, F. (2021). XPS, SEM, DSC and Nanoindentation Characterization of Silver Nanoparticle-Coated Biopolymer Pellets. Appl. Sci. 11, 7706. https://doi.org/10.3390/app11167706.

Neves, A.C.C.; Rohen, L.A.; Mantovani, D.P.; Carvalho, J.P.R.G; Vieira, C.M.F.; Lopes, F.P.D.; Simonassi, N.T.; Luz, F.S.; Monteiro, S.N. (2020). Comparative mechanical properties between biocomposites of Epoxy and polyester matrices reinforced by hemp fiber. Journal of materials research and technology. 9 (2), 1296-1304. https://doi.org/10.1016/j.jmrt.2019.11.056.

Omrani, E.; Menezes, P. L.; Rohatgi, P. K. (2016). State of the art on tribological behavior of polymer matrix composites reinforced with natural fibers in the green materials world. Engineering Science and Technology, an International Journal. 18, 717-736. https://doi.org/10.1016/j.jestch.2015.10.007.

Peças, P.; Carvalho, V. H.; Salman, H.; Leite, M. (2018). Natural Fibre Composites and Their Applications: A Review. Journal of Composites Science. 2 , 66. https://doi.org/10.3390/jcs2040066.

Pereira, A. S., Shitsuka, D. M., Parreira, F. J. \& Shitsuka, R. (2018). Metodologia da pesquisa científica. Núcleo de Tecnologia Educacional -UFSM.

Rajak, D.K.; Pagar, D.D.; Menezes, P.L.; Linul, E. (2019). Fiber-Reinforced Polymer Composites: Manufacturing, Properties, and Applications. Polymers. 11, 1667. https://doi.org/10.3390/polym11101667.

Reis, R.H.M.; Garcia Filho, F.C.; Nunes, L.F.; Candido, V.S.; Silva, A.C.R.; Monteiro, S.N. (2021). Impact Resistance of Epoxy Composites Reinforced with Amazon Guaruman Fiber: A Brief Report. Polymers. 13, 2264. https://doi.org/10.3390/polym13142264.

Ribeiro, M. M. (2015). Comportamento em tração/flexão e aspecto fractográfico de matriz poliéster com pó de aerosil e de madeira com a inclusão de fibras curtas de sisal e jute. Dissertação (Mestrado) - Universidade Federal do Pará, Instituto de Tecnologia, Mestrado em Engenharia Mecânica, Belém.

Rodrigues, J. S. (2008). Comportamento mecânico de material compósito de matriz poliéster reforçado por sistema híbrido fibras naturais e resíduos da indústria madeireira. Dissertação (Mestrado) - Universidade Federal do Pará, Instituto de Tecnologia, Mestrado em Engenharia Mecânica, Belém.

Santos, J.K.D.; Dantas Da Cunha, R.; De Amorim Junior, W.F.; Felipe, R.C.T.S.; Braga Neto, J.L.; Freire Júnior, R.C.S. (2020). The variation in low speed impact strength on glass fiber/Kevlar composite hybrids. Journal of Composite Materials. 54, 3009-3019. https://doi.org/ 10.1177/0021998320906205.

Simonassi, N.T.; Pereira, A.C.; Monteiro, S.N.; Margem, F.M.; Deus, J.F.; Vieira, C.M.F.; Drelich, J. (2017). Reinforcement of Polyester with Renewable Ramie Fibers. Materials Research. 20, 51-59. https://doi.org/10.1590/1980-5373-MR-2016-1046.

Souza, L. G. M.; Silva, E. J.; Souza, L. G. V. M. (2020). Obtaining and Characterizing a Polyester Resin and Cement Powder Composites. Materials Research. 23, 1-8. https://doi.org/10.1590/1980-5373-MR-2018-0894.

Uppal, N.; Pappu, A.; Patidar, R.; Gowri, V. S. (2019). Synthesis and characterization of short sisal fibre polyester composites. Bulletin of Materials Science, 42(3), 1-8. doi:10.1007/s12034-019-1792-6. 